\title{
Ottoman Policy during the Bulgarian Independence Crisis, 1908-9: Ottoman Empire and Bulgaria at the Outset of the Young Turk Revolution
}

\author{
HASAN ÜNAL
}

There have been some studies about the dealings of the Young Turks, while in power 1908-18, with the Europeans Great Powers, but very little has been written about their policies towards the Balkan states during the period in question. A possible explanation for this dearth of scholarly research on the Young Turks' Balkan policies is that many experts appear to think that the Balkan states, small in size and dependent on Great Power Patrons were of negligible importance in Ottoman strategic planning and, therefore, played second fiddle, at best, in the Porte's policy formulation to the Great Powers which had the determining influence on the Empire's external policies. However, archival documents suggest that the Balkan states did have an important, if not decisive, impact on the Ottoman Empire's foreign policy-making process. An attempt will be made in this essay to prove that the Balkan states were in a position to deal a serious, if not mortal, blow to the Ottoman Empire in the early twentieth century. This will be done by analysing the strategic thinking of the Ottoman military and the civilian administration, and by pointing to Ottoman concerns vis-à-vis Bulgaria during the Bulgarian independence crisis. However, before embarking upon an analysis of Ottoman policy formulation during that crisis, it is best to glance at the Empire's policies towards the Balkans during the last decades of the nineteenth and early years of the twentieth centuries.

Towards the end of the nineteenth and early twentieth centuries, in particular, it was becoming hard for the Ottoman Empire to play off the Powers against each other, a game quite successfully played by Abdülhamid II during his long reign. ${ }^{1}$ The obvious reason for that was that the Powers, which had long been at each other's throats either due to their colonial disputes or because of mutual suspicions about their intentions on the Continent, were edging towards each other. The division of the Powers into two camps was taking shape. This was in turn narrowing the room for 
manœuvre for the Ottoman Empire, making the Empire's relations with the Powers increasingly problematic though there was not yet an immediate threat to the Empire's political existence. But the outlook in the Balkans was quite disturbing. The potential for hostility between the Balkan states and the Ottoman Empire was self-evident. Greece, Serbia, Montenegro and Bulgaria were trying to eat up the Empire. All of these states and Romania owed their existence to national revolts against Ottoman rule, and Romania excepted, all harboured well-advertised, though conflicting, designs upon the Ottoman Empire's remaining Balkan territories. Even so, for most of the nineteenth century these designs had not ranked as the principal threat to Ottoman security: the small Balkan states remained politically and militarily weak, and were easily dominated by the Great Powers. ${ }^{2}$ From the late 1890 s onwards, however, this picture began to change. The Balkan states were growing in wealth and population, ${ }^{3}$ and emancipating themselves from the diplomatic tutelage of Great Power patrons. Above all, they were emerging as significant military powers in their own right, capable of posing independent threats to the Ottoman Empire: the Bulgarians in particular were building up an impressive modern army, while the Greeks were laying the foundations of a modern navy. By 1900 the balance of power in the Balkans was fast turning against the Ottoman Empire. ${ }^{4}$

The consequences of these adverse international shifts were revealed in the Macedonian question. Macedonia, the core of the Ottoman Balkans, was a mixture of Turkish, Bulgarian, Albanian, Greek, Serbian, Vlach and Jewish populations. Greece, Bulgaria, Serbia and even Romania had longstanding ambitions in the region, and for decades these states had striven to build up their own rival parties among the Christian population through peaceful propaganda. ${ }^{5}$ To this, Abdülhamid's regime responded with a policy of 'divide and rule', seeking to retain the loyalty of the Muslim Turks and Albanians, while also playing off the rival Christian nationalities against one another. ${ }^{6}$ In the late 1890 s, however, the Bulgarian element in Macedonia turned to violent methods: under the leadership of a political group conventionally referred to as the Internal Macedonian Revolutionary Organization (IMRO), ${ }^{7}$ it embarked upon a campaign of agitation and terrorism against the Ottoman authorities, with the professed aim of securing a system of autonomous administration for Macedonia. Nonetheless, it was widely believed that the real objective of IMRO and its adherents was the eventual absorption of Macedonia into the neighbouring Principality of Bulgaria. In 1903 IMRO launched the unsuccessful Ilinden uprising against Ottoman rule; ${ }^{8}$ the outcome was a low level civil war in Macedonia which lasted until the Young Turk revolution of 1908. Bulgarian armed bands harassed the Ottoman administration and army; Turks and 
Albanians organized counter-bands; with the more or less open toleration of the Ottoman authorities, the local Greeks, Serbs and Vlachs also organized armed bands to fight the Bulgarians. ${ }^{9}$

In a broader sense, Ottoman-Bulgarian relations were quite tense on the eve of the Young Turk revolution. Nevertheless, the Sultan was bold enough to appeal to the Bulgarian government during the difficult days of the Young Turk revolution. It seems that when he ran out of options in crushing the armed rebellion which erupted in various parts of Ottoman Macedonia, he contemplated provoking a frontier crisis with Bulgaria as a means of diverting attention and restoring the solidarity of the army, large parts of which had by then turned against him..$^{10}$ The crisis, it should be added, was to have been created in connivance with the Bulgarian government.

According to Bulgarian sources, the Sultan's right-hand man, Kâmil Bey, the Ottoman Imperial Commissioner at Sofia, approached the Bulgarian Foreign Minister, Paprikov, with the following offer: Bulgaria should move troops towards the frontier to divert the forces of the Young Turks and thereby indirectly assist Abdülhamid in his attempt to crush the rebellion. It appears that even after the proclamation of the constitution, Kâmil Bey continued to press Paprikov to send troops to the border or to take other military measures to divert attention at home. ${ }^{11}$ It also appears that other diplomatic missions got wind of these démarches by Kâmil Bey. For instance, Sir George Buchanan, the British representative at Sofia, reported to London on 1 August that the Ottoman Commissioner had approached Paprikov with such an offer. ${ }^{12}$ According to French documents, Russia's diplomatic mission at Sofia was aware of Kâmil Bey's proposal, and the Russians even tried to exchange information with the French about that. ${ }^{13}$ The First Grand Vizier who took office after the restoration of the 1876 Constitution, Said Pasha, confirmed all these rumours in an interview to the Chief British Dragoman, G.H. Fitzmaurice, that the Sultan 'rather than consent to the revival of the Constitution, had thought of creating complications with Bulgaria and even other Powers'. ${ }^{14}$

When Abdülhamid finally threw in the towel on 23 July by agreeing to the proclamation of the constitution, and after the appointment of Kâmil Pasha to the Grand Vizirate on 6th August, the involvement of the Committee of Union and Progress (hereafter CUP) in foreign policy-making became the order of the day. From the start, there existed scope for disagreement between Kâmil Pasha and the CUP over foreign affairs. And all this seems to have affected the Ottoman government's handling of Bulgaria during the crisis which erupted when Bulgaria declared full independence from the Empire in October 1908, coupled with the corresponding announcement by Austria-Hungary of the an nnexation of Bosnia and Herzegovina left under Austro-Hungarian occupation since 1878. 
The Young Turks, widely known as the CUP in Turkish historiography, had been indulging in foreign policy analysis since 1902. A cursory look at their publications and the CUP secret communications while in opposition reveal that those Young Turks who later became influential in Ottoman politics following the proclamation of the Constitution of 1908 embraced some sort of a nationalism from 1906 onwards. But their nationalism was laced with a strong dose of 'Turkishness' as opposed to the Ottomanism of the previous decades. From the perusal of their assessments of foreign affairs, two principal observations may be made. First, the CUP exhibited a marked hostility and suspicion towards all the Powers, great and small, including Bulgaria and all other Balkan states, and a strong resentment of their interference in Ottoman internal affairs. Manifesting no special sympathy towards any Power, the CUP made no bones about its deep-rooted suspicion with regard to Bulgaria in particular, and other Balkan states in general. Second, the CUP was always at pains to disguise its Turkish nationalist, and by implication, anti-Christian leanings especially in its Ottoman-Turkish publications. ${ }^{15}$

At the outset of the Young Turk revolution, there remained a fundamental question: whether and how these nationalist leanings could be made use of in moulding foreign policy. The Bulgarian independence crisis which erupted soon after the Young Turk revolution of 1908 appears to have been taken by the CUP leadership as an opportunity for exercises in foreign policy-making for about six months. During this period prominent members of the CUP played an important role in Ottoman foreign policy-making though the Grand Vizier Kamil Pasha did not always see eye to eye with them. ${ }^{16}$ And these fundamental differences between the Grand Vizier and the CUP in policy assessments as well as in practical approaches during the crisis were to cause muddling in Ottoman policy-making.

The Grand Vizier had clear views on the subject of the Empire's relations with the Balkan states. During the 1880 s and early 1890 s he had been known as something of a Bulgarophile, tolerating Bulgaria's absorption of Eastern Rumelia in 1885 and arguing that the Empire's security was best assured by close relations with Sofia. ${ }^{17}$ With the emergence of a serious Macedonian problem after 1903, however, his attitude changed: he then began to speak of Bulgaria as a fundamentally hostile state, whose national ambitions posed a major security threat to Ottoman territorial integrity. In 1905, for instance, he urged Abdülhamid to conclude an alliance with Greece and Romania as the best means of containing the territorial ambitions of Bulgaria, and of its fellow-Slav states, Serbia and Montenegro. He made plain his fear that Bulgaria was preparing for a war with the Empire, perhaps to be launched in conjunction with an armed uprising in Macedonia, and that it might seek to gain the alliance of 
the other Balkan states by proposing a mutual partition of the Ottoman Empire's Balkan territories. He even argued that an alliance between the Empire, Greece and Romania would be the best means of deterring Bulgaria from war: it might also enable the Empire to drive a wedge between Bulgaria, on the one hand, and Serbia and Montenegro, on the other. ${ }^{18}$ Over the following years, Kâmil Pasha continued to express considerable pessimism about the course of Ottoman-Bulgarian relations; indeed, shortly before the Young Turk revolution, he suggested to Abdülhamid that a war between the Empire and Bulgaria was likely sooner or later. ${ }^{19}$

As to the CUP, in the immediate aftermath of the Young Turk Revolution, its underlying anti-Europeanism and lack of any firm diplomatic preferences were expressed in vague professions of friendship for every power, big and small. While a number of CUP emissaries, mostly members of the CUP's inner circle, tried to cultivate relations with representatives of the Great Powers, ${ }^{20}$ other prominent members were pursuing independent diplomatic contacts with the Balkan states, though here too the contacts were vague in content, and gave no convincing indication of diplomatic preference. The CUP leadership endeavoured to make use of its contacts, which it had established prior to the revolution, with various revolutionary groups in Macedonia, Bulgarian, Greek or other, to further its relations with the Balkan states to which these communities in Macedonia looked for advice and support. The Bulgarian groups, which had been on the point of exhaustion by the outbreak of the Young Turk revolution, were assisted by the CUP in various places, where the Greek armed bands were told to desist from further attacks on the Bulgarian community. ${ }^{21}$ Fallen Bulgarian bandit leaders were exalted as 'heroes' by the CUP in various parts of Macedonia. ${ }^{22}$ The CUP's pro-Bulgarian demonstrations soon reached a point where some representatives of the Powers at Constantinople thought that an alliance between Constantinople and Sofia was imminent. ${ }^{23}$ In this, however, they proved mistaken. The CUP was anxious not to antagonize the Greek element in Macedonia. It continued the intimate relations which it had built up over the years with the Greek revolutionary groups, ${ }^{24}$ and although certain Greeks do not seem to have been enthusiastic about collaborating with the CUP, the CUP's relations with the Greeks remained satisfactory right up to the Bulgarian independence crisis. ${ }^{25}$

The crisis which broke out at the beginning of October 1908 offered a serious and sustained test of the foreign policy of the new Ottoman regime and of its two principal components: the anti-Hamidian statesmen of the old regime who predominated in Kâmil's cabinet, and the CUP which had assumed the role of guardian of the revolution. For the European Powers, it was the issues arising out of Austria-Hungary's annexation of BosniaHerzegovina which loomed largest: not surprisingly, many historians refer 
to the international crisis of October 1908-April 1909 as the 'annexation crisis' ${ }^{26}$ For the Ottoman Empire, however, it was the issue of Bulgarian independence which took precedence, for pressing political and strategic reasons.

For decades, following the establishment of a fully autonomous Bulgaria under the suzerainty of the Ottoman Empire at the Berlin Congress, the objective of formal independence was a secondary priority in Sofia's policymaking because consecutive Bulgarian governments had been 'busy' in Ottoman provinces, first Eastern Rumelia and then Macedonia. Following the absorption of the former, Sofia governments resorted to aggressive policies in Ottoman Macedonia in the late $1890 \mathrm{~s}$ through to $1908 .{ }^{27}$ But the Young Turk revolution put Bulgaria on the spot, taking Sofia's government completely by surprise and utterly unawares: indeed, Prince Ferdinand was abroad, and Malinov's Democratic Party cabinet maintained an absolute public reserve: only after some three weeks, under pressure from the opposition, did the semi-official newspaper Pryaporets announce that it was abstaining from approval or disapproval until the shape of the future Ottoman administration was definitively established. ${ }^{28}$ This official reserve seems to have reflected genuine uncertainty as to the import of the revolution in the Ottoman Empire, and as to its likely impact upon Bulgaria's interests, above all, in Macedonia. In the long term, as viewed from Sofia, the revolution might conceivably herald the Empire's descent into anarchy and final dissolution, but it might also presage the Empire's revival. The short-term outlook was equally obscure. Optimists believed that the new constitutional regime would facilitate Bulgaria's programme of Macedonian autonomy: they were encouraged by the CUP's friendly overtures to the Bulgarian element in Macedonia, ${ }^{29}$ and saw the revolution as a blow to Greek and Serb aspirations in the region. Reporting to Prince Ferdinand on $25 \mathrm{July}$, two days after the restoration of the constitution Paprikov declared:

In a few days Macedonia has become unrecognizable ... In a word something inexplicable and improbable has happened. The frontier is open and entry into Macedonia is most free, the fallen Bulgarian chetniks are exalted even by the Turks as popular heroes. ${ }^{30}$ All this is improbable, but it is true; that which the revolution has given to the Macedonians in ten days, the reforms could not have given in as many years. Now in Macedonia, the Serbian element no longer exists, that which Serbia has built up over long years has collapsed in a week. The Greeks have lost a great deal. However things may turn out hereafter, the position of the Bulgarian element is affirmed... ${ }^{31}$ 
On the other hand, pessimists were quick to point to the Young Turks' underlying nationalism, to their ambitions to revive the Ottoman Empire as a unitary state, and to rumours that the CUP had plans to undermine the established cultural and communal privileges of the Empire's non-Muslim populations, including its Bulgarians. Above all, the Powers' willingness to abandon their various reform projects in Macedonia caused serious concern, by closing off one route to Macedonian autonomy. When the British Foreign Office announced that it had suspended all representations to the Porte for the creation of a mobile force in Macedonia, and would also withdraw its gendarmerie officers from the region, the Bulgarian Agent at London retorted that the Young Turk revolution was totally 'illusory', and that nothing useful was to be hoped for from it. ${ }^{32}$

While Bulgarian authorities were weighing the pros and cons of the Young Turk revolution, the first practical proposal as to what to do came from Ivan Geshov, the Bulgarian agent at Constantinople. He suggested as early as 1 August that Bulgaria should respond to the revolution with a declaration of independence:

... the Young Turk revolution is not something good for Bulgaria ... because it is clear that the revolution pushed away from Bulgaria at a still greater distance the solution of the Macedonian question as we have understood it and as we have yearned for it... My conclusion is that in the final analysis, we, as a state, lose from the revolution because it has displaced the Macedonian question and our position in it has been significantly weakened ... As we lose by the Young Turk coup, we are obliged to seek some revenge. At today's time, this cannot be other than the full independence of Bulgaria ... ${ }^{33}$

It appears that Geshov's stance was soon adopted by Paprikov, and that by mid-September, following discussions between Malinov and Prince Ferdinand in Hungary, it had been decided to take early steps to procure Bulgaria's full and formal independence from the Ottoman Empire. This was a decision in principle only. The question of timing was left open, as was the question of means: indeed, there are indications that at this stage the Bulgarian government had hopes of achieving independence by agreement through direct negotiations with the Porte and the CUP. ${ }^{34}$

As it turned out, however, Bulgaria's path to independence was anything but harmonious. From mid-September onwards, relations between Constantinople and Sofia deteriorated markedly, with the result that Bulgaria's declaration of independence, when it came, took the form of an act of open hostility towards the Ottoman Empire. The first stage in this deterioration of Ottoman-Bulgarian relations arose with the 'Geshov Incident' of September 1908. This incident was triggered off by the 
Ottoman government's failure to invite Geshov, in his capacity as Bulgaria's agent in Constantinople, to a banquet for the Diplomatic Corps held in honour of the Sultan's birthday on 12 September. It is not clear what had prompted the Porte to withhold the invitation, ${ }^{35}$ or indeed, whether its decision was deliberate. On the one hand, as the Porte was subsequently to argue, Geshov was the representative of a vassal state, and as such, not an accredited member of the Diplomatic Corps: the question of an invitation did not arise. On the other, there was some speculation that the new Ottoman regime was determined to re-emphasize its rights as Bulgaria's formal suzerain, ${ }^{36}$ and that its action in not inviting Geshov was a calculated 'snub' or provocation. ${ }^{37}$ There is even some doubt as to what passed between Kâmil Pasha and Geshov when the latter first came to the Porte to complain. According to what Geshov told an Ottoman journalist, the Grand Vizier had said that 'you will not be invited because Bulgaria is a Principality under Turkey, whereas the banquet has been arranged for foreign representatives' ${ }^{38}$ But, according to Kâmil Pasha's subsequent account, Geshov had failed to inform him of his displeasure; had he done so, Kâmil added, the incident could easily have been avoided, as the Porte would have invited Geshov in company with some other senior officials, thus giving the banquet a less exclusively diplomatic character. ${ }^{39}$

Be that as it may, it soon became clear that neither side was willing to concede, and the attempts of Marschall and Pallavicini, respectively ambassadors of Germany and Austria-Hungary, to mediate proved fruitless. ${ }^{40}$ The Bulgarian government instructed Geshov to leave Constantinople should the Porte not give way, and Geshov duly withdrew to Sofia on 13 September, the day after the banquet. ${ }^{41}$ At this stage, neither side seemed prepared to force a more serious breach. The Bulgarians appear to have sensed that the Geshov Incident could not of itself justify a declaration of independence, ${ }^{42}$ while the Ottoman government professed itself anxious to smooth matters over.

The Ottoman Imperial Deputy-Commissioner at Sofia, Refik Bey, was quick to express his surprise to Paprikov at Geshov's sudden arrival in Sofia, 'at a time when good relations between the two countries needed to be strengthened'. He asked Paprikov to send Geshov back at once, before the whole matter became known to journalists. Paprikov, for his part, expressed concern at the straining of relations, but he made it clear to Refik Bey that the Bulgarian government could not stomach the 'treatment' to which their agent had been subjected, and warned that his return to Constantinople was out of the question until and unless the Ottoman government apologized profusely for its behaviour, reassuring Bulgaria that its agents at Constantinople would never be treated similarly again. Paprikov went so far as to threaten that if the official diplomatic title of 
their agent to the Porte was not to be recognised as it had been in the past, the Bulgarian government would, in his personal opinion, feel the need to reduce the title of the Ottoman Imperial Commissioner to that of Commissioner for Religious Foundations' (Vakıf Komiseri).$^{43}$

At this stage, the dispute still centred upon the technical issue of the invitation to the banquet. According to Refik Bey, the Bulgarians argued that their agents at Constantinople had been invited to ceremonial occasions in the Palace together with foreign representatives on previous occasions, most recently when Geshov and other accredited diplomats had offered their congratulations to the Sultan on his proclamation of the constitution. ${ }^{44}$ The Porte replied with a denial that Bulgarian agents had previously attended all official receptions, and added that none of the occasions when they had been received could be regarded as official, or exclusively reserved for diplomatic 'Chefs des Missions'. As to Geshov's presence at the Palace on the occasion of the proclamation of the constitution, the Porte added, this was the responsibility of the Acting Doyen of the Diplomatic Corps, not of the Sublime Porte. ${ }^{45}$ Even so, Refik Bey seemed optimistic that the episode could be smoothed over: he reported that the attitude of the Bulgarian press was 'moderate and prudent'. ${ }^{46}$

However, on 16 September, Refik Bey struck a less optimistic note, reporting rumours that Geshov's recall from Constantinople had been designed behind the back of the government by the Bulgarian diplomatic agents at Paris and St Petersburg, with a view to ousting the Bulgarian foreign minister in the ensuing diplomatic squabble. There were apparently those who believed that as Prince Ferdinand had, with the advent of the Young Turk Revolution, despaired of becoming 'King of Macedonia', he now thought that by 'insulting' Geshov the Turks were intending to inflict another blow to his domestic standing. ${ }^{47}$ Before any progress could be made towards a satisfactory resolution of the Geshov Incident, OttomanBulgarian relations took a further turn for the worse when, on 20 September, Bulgarian troops seized the section of the Oriental Railway passing through Eastern Roumelia. ${ }^{48}$

What apparently prompted the seizure of the railways was what the Bulgarians regarded as yet another humiliating example of the Ottoman Empire's determination to re-emphasize Bulgaria's vassal status. Following the Young Turk revolution, strikes among workers, hitherto prohibited, had broken out all over the Empire, particularly in urban centres. This wave of strikes had eventually affected the Oriental Railway Company's Constantinople depot. The Porte, it appears, was anxious that this particular strike should not spread to the company's workers in Eastern Rumelia in Bulgaria, for otherwise, coming on the heels of the Geshov Incident, it might offer Sofia further ground for complaint and protest. In order to forestall this 
contingency, the Ottoman government immediately dispatched a group of military officers to Eastern Rumelia in a specially prepared train, with instructions to talk the workers out of going on strike. To the Bulgarian government, however, this direct intervention by the Porte in Eastern Rumelia was quite unacceptable. ${ }^{49}$ Troops on the frontier point were ordered not to allow in the Ottoman officers; meanwhile the Oriental Railway Company's workers came out on strike.

Faced with the outbreak of the strike, the Company felt that it had no choice but to ask the Bulgarian railway authorities to take over the lines and run them until the strike was over, and on 20 September the lines were duly occupied. It was soon apparent that this occupation was intended to be permanent. The Bulgarians had long resented the Oriental Railway Company's presence in Eastern Rumelia, seeing it as a reminder of their vassal status, and even though the strike was over within one or two days in certain sections, the Bulgarian railway authorities categorically refused to allow the Company's officials to resume normal work..$^{50}$ On 22 September, Colonel Mehmed Şükrü Bey reported from the Ottoman Imperial Commission at Sofia that the Bulgarian authorities were explaining their refusal to return the lines as a temporary measure, whose purpose was to force the Company to compensate Bulgaria for losses of trade suffered during the strike; he suggested, however, that the Bulgarian government's real intention was to nationalise the lines, and reported rumours that the financial aspects of nationalization were already under discussion. ${ }^{5 t}$

Meanwhile the Oriental Railway Company itself asked the Porte to take steps to secure the return of the lines. ${ }^{52}$ However, on 24 September the Bulgarian government warned the Porte off. In a note-verbale delivered to the Ottoman Commission in Sofia, it explained that:

la prise de l'exploitation des chemins de fer de la Compagnie Orientale par l'administration des Chemins de fer bulgares a eu lieu par suite de la grève et sur une entente avec le représentant de la Compagnie des Chemins de fer. Toutefois, la remise de l'exploitation de cette ligne ferrée à la susdite Compagnie est une question qui sera réglée entre le gouvernement Princier et la Compagnie des Chemins de fer Orientaux..$^{53}$

In a separate memorandum to the Powers, the Bulgarian government alleged that the strike had been engineered by the Porte with a view to paralysing vital railway lines in Bulgaria, and that it could not consider the strike terminated. $^{54}$

Coming hard on the heels of the Geshov Incident, and being accompanied by the first rumours of a Bulgarian mobilization, the railway dispute cast an ominous light on Bulgaria's intentions, and the Grand Vizier 
was quick to sense that a declaration of independence might follow: he instructed the Foreign Minister, Tevfik Pasha, to approach the governments of Greece, Serbia and Romania, and ascertain their likely reactions to such a move. At the same time, however, he sought to appease Sofia, instructing Refik Bey on 26 September to remind the Bulgarian government of the benevolent role he had played during the Eastern Rumelian crisis of 1885 , and to express his anxiety to close the Geshov Incident. ${ }^{55}$ Three days later Refik Bey replied that Malinov had expressed his and Prince Ferdinand's regret that the Geshov Incident should have occurred, though without abandoning their insistence that the Bulgarian side had been in the right throughout; as to the railway dispute, however, Malinov had given no clearcut answer, except to mention the possibility of offering the Ottoman government some compensation for Bulgaria's take-over of the lines. ${ }^{56}$

By now, the Bulgarian government had made up its mind to press ahead to formal independence. It still had hopes of doing so with the Porte's agreement, and apparently instructed its Commercial Attaché in Salonica, Shopov, to make a confidential approach to the CUP. According to Shopov's reports, his CUP contacts expressed their desire to be on the best possible terms with Bulgaria, and stated that the question of independence for Bulgaria could, at an appropriate moment, easily be settled between two friendly countries. Paprikov in turn empowered Shopov to suggest to the CUP that it should oblige the Ottoman government and the Sultan to recognise Bulgaria as an independent state; in return, 'we are not far from the idea that we should enter into an alliance which will be useful for both sides'. On 25 September, however, Shopov replied that the CUP was of the opinion that it could not possibly take the initiative in getting Bulgaria recognised, but that it would be quite a different matter should it be placed before a 'fait accompli'. According to Shopov, the CUP believed that a sincere agreement between Constantinople and Sofia would strengthen their regime, whereas a serious rupture of relations between the two countries would undermine their authority and create favourable terrain for a resurgence of reaction within the Empire. Therefore, in their conversations with Shopov, they stressed that they desired an agreement and an alliance with Bulgaria, emphasizing that 'the question of independence for Bulgaria is nothing in comparison with the important and great idea of serious and lasting agreement between Turkey and Bulgaria'. ${ }^{77}$

Shopov was not Bulgaria's only channel. It appears that the Bulgarian government also sent Konstantin Hadzi Kalchov, an old acquaintance of Kâmil Pasha, to Constantinople for talks with the Grand Vizier, as well as with Ahmed Riza and other CUP representatives.$^{58}$ Little is known about this mission, though it appears that Hadzi Kalchov subsequently claimed that his mission was remarkably successful: he persuaded the CUP to agree to the 
transfer of the Eastern Rumelian railways to Bulgarian control, though without mentioning the question of ultimate ownership, and he also persuaded the CUP to agree in principle to the recognition of Bulgarian independence. According to the plan, worked out between Hadzi Kalchov and the CUP and the Grand Vizier, Kâmil Pasha, was to have paid an official visit to Sofia during which Bulgaria was to have been proclaimed an independent kingdom with the approval of the Sultan. ${ }^{59}$ Whatever the truth of these claims, it is clear that the Grand Vizier remained anxious to avoid an open breach with Sofia, and at the beginning of October he asked the Bulgarian government to send Grigor Nachovich, a Bulgarian statesman of pronounced pro-Ottoman leanings ${ }^{60}$ to Constantinople for talks. However, Sofia refused this request. ${ }^{61}$

At this stage, the Powers began to sense the seriousness of the situation: almost all pointed out that the Ottoman side had been legally in the right. But they expressed a wish to see the whole matter closed. They even warned Sofia of the consequences of a declaration of independence. The British in particular made the strongest representations at Sofia. But by the beginning of October it was clear to London that these warnings had failed to produce the desired effect: rumours of an impending declaration of independence by Bulgaria were growing. The British chose to take the diplomatic lead, and on 2 October they issued a circular calling on the Powers to urge restraint upon Sofia. Austria-Hungary in particular was asked to bring pressure on Prince Ferdinand, who was then in Budapest. France and Germany at once accepted the British proposal..$^{62}$ So did the Russians, who even expressed readiness to join in representations with the other Powers, but they independently reminded the Bulgarian government of the dangers with which a declaration of independence would be beset. As a last resort, the Russian Minister at Sofia, on instructions from his government, suggested that the declaration of independence be postponed until March 1909, by which time the issue might be resolved by means of negotiations. It is interesting to note that the only Power which did not join in the representations, and which professed disbelief that a Bulgarian action was imminent, was Austria-Hungary. ${ }^{63}$

However, none of these warnings on the part of the Powers made any impression upon the Bulgarian government. ${ }^{64}$ Though the Bulgarian government was well aware of the dangers a declaration of independence would involve, the rumour that Austria-Hungary was about to announce the annexation of Bosnia and Herzegovina was sufficient encouragement for Sofia to press ahead. Having personally obtained Prince Ferdinand's blessing in Austria-Hungary, Malinov returned to Sofia, where on 29 September the cabinet formally agreed to proceed to a unilateral declaration of independence. It was decided that the declaration should be made at 
Veliko Tarnovo on 5 October, as soon as Prince Ferdinand returned to Bulgaria. ${ }^{65}$

The Bulgarian declaration of independence took place against a background of speculation that the Sofia government might be preparing to launch an invasion of the Ottoman Empire, and for much of October fear of a Bulgarian attack was the single most important factor in the Porte's strategic planning. From late September onwards, in fact, the Ottoman government received a stream of reports from the military officers attached to its Commission at Sofia, all suggesting that the Bulgarian army was conducting a major mobilization under the cover of its annual autumn manœuvres. The first reports were confused, and led the Ottoman War Ministry and the General Staff to ask for clarification: the Commission replied that it had no funds to support an extensive espionage service, and added for good measure that its own officers' salaries were some four months in arrears. ${ }^{66}$ Nevertheless, the picture soon grew clearer and more disquieting. The War Ministry received information that the reservists summoned to the Bulgarian army's manœuvres might not be discharged, or that if they were, their places would be taken by other reservists. ${ }^{67}$ It also learned that the Bulgarian army's contingency plans for war with the Ottoman Empire envisaged the delivery of an early knock-out blow, taking advantage of the Bulgarians' superior mobilization speed, and that there was a belief in Sofia that the Young Turk revolution and its attendant domestic confusion offered Bulgaria an opportunity for a successful offensive campaign. ${ }^{68}$ The Commission also reported the alarming news that the Bulgarian government was preparing to instigate trouble in Macedonia: it had allegedly distributed 50 million francs to its 'agents-provocateurs' in the region, had equipped them with a printing-press, and was granting generous 'severance payments' to Bulgarian officials who would go to Macedonia. ${ }^{69}$

By the time the declaration of independence took place, the situation on the Empire's frontier with Bulgaria looked ominous. The Bulgarian army had mobilised between 100,000 and 115,000 men, ${ }^{70}$ and there were suggestions that this number might shortly be increased to $215,000 .{ }^{71}$ True, the message in which Prince Ferdinand announced the declaration of independence to the Sultan was couched in conciliatory terms. ${ }^{72}$ But, it was followed by further alarming news of Bulgarian military preparations: the Sofia government had allegedly ordered 200,000 kilograms of rations for its troops, for delivery by the end of October; ${ }^{73}$ troops were being moved towards the frontier, ${ }^{74}$ and the mobilization of reservists accelerated; arms were being distributed to the population in districts bordering on the Empire. ${ }^{75}$

Measures of counter-mobilization were set in train by the Ottoman military authorities, but it was obvious that the Bulgarians had a 
considerable head start: the Ottoman army was in no position to launch an offensive campaign against Bulgaria. ${ }^{76}$ This effectively ruled out any military response to the declaration of independence, and when the Ottoman cabinet met on 7 October, the War Minister stated the position bluntly: 'We don't even have rawhide shoes for our soldiery to put on, let alone fight.' Kâmil Pasha threw the blame onto the ex-War Minister Riza Pasha, maintaining that he had done nothing but accumulate personal wealth during his long term of office. The Porte decided that it must find a way out through diplomacy, and postponed a reply to Ferdinand's message until it had consulted the Powers; it also decided to ask the Powers to restrain Bulgaria from further mobilization. ${ }^{77}$

The Powers' responses were generally favourable. Britain, France, Italy, Germany and Russia all deprecated Prince Ferdinand's violation of the Treaty of Berlin, and indicated that they would abstain from recognizing Bulgaria's independence. In addition, all these Powers promised to instruct their representatives at Sofia to press the Bulgarian government from further measures of mobilization, or any steps that might endanger the peace. Only Austria-Hungary refused to follow suit on the grounds that it had no information suggesting that the Bulgarians were preparing for war. ${ }^{78}$

Having been reassured that a majority of the Powers would not recognize Bulgaria's independence, the Porte was finally able to send a reply to Prince Ferdinand on 13 October, reminding him that the international status of Bulgaria had been defined by international treaties signed by the Powers and the Ottoman Empire, and could not be altered by a unilateral act by Sofia. To rub the point in, the reply was sent in the name of the Grand Vizier and not of the Sultan, as a formal reminder of Bulgaria's vassal status. ${ }^{79}$ The result was a further increase in Ottoman-Bulgarian tension: Prince Ferdinand complained that the reply was 'insolent', and threatened to order a general mobilization. ${ }^{80}$

Thereafter the tension gradually eased. On 15 October Refik Bey reported from Sofia that the Bulgarian cabinet, which had been in secret session for some days, ${ }^{81}$ had finally ruled out a military solution in favour of a settlement through negotiations. ${ }^{82}$ Two days later an Ottoman journalist arrived in Sofia, conveying a message from the Grand Vizier to the Bulgarian government: this indicated that the Porte was ready for direct bilateral negotiations, and would not necessarily prefer to leave matters to a conference of the Powers. ${ }^{83}$ On 19 October the Bulgarian government despatched Dimitrov, the Secretary-General of the Foreign Ministry, and Stoyanovich, the Director of the Posts and Telegraphs, to hold talks with the Grand Vizier at Constantinople. The details of the discussions between these two emissaries and Kâmil Pasha have not been traced, though it appears that the Grand Vizier at first took a tough line, insisting that Sofia must pay 
substantial financial compensation for its independence, and even hinting that Bulgaria should abandon Eastern Rumelia. ${ }^{84}$ Evidently this was not his final word, for the outcome of the discussions was neither a rupture nor a revival of tension; instead, as will be seen, the Bulgarian government sent a higher-level mission to Constantinople for further talks at the end of the month. ${ }^{85}$

In the meantime the CUP had also taken steps to calm the situation. It despatched two emissaries to Sofia, Lieutenant-Colonel Faik Bey and Major Fethi Bey, hoping not only to contact the Bulgarian government but also to influence Bulgarian public opinion, where partisans of good relations with the Ottoman Empire had already responded to the Young Turk revolution by forming an 'Allied Committee for Political, Economic and Cultural Rapprochement between Bulgaria and Turkey'. ${ }^{86}$ Addressing a gathering of this association, Faik Bey and Fethi Bey stressed that it was, after all, the Bulgarians in Macedonia and Bulgaria who had taken up the most sympathetic attitude towards the Young Turk revolution, and that a war between the two countries would ruin them both. ${ }^{87}$. The Bulgarian association, for its part, responded warmly to the CUP emissaries' call to prevent war. The upshot was a joint declaration to the effect that 'the populations of both countries are against an armed conflict, for which there exist no motives, and expect both governments not to decide to disturb the peace against the will of their peoples'. The two committees also vowed to do all in their power to influence their respective governments towards a rapprochement between Bulgaria and the Ottoman Empire. ${ }^{88}$

There are some indications that the Bulgarian government, too, was anxious to deal directly with the CUP. On 19 October the British ConsulGeneral in Salonica reported that he had been approached by his Bulgarian colleague Shopov, who had requested the use of the consulate's telegraph facilities. Shopov had explained that he was about to enter into negotiations with the CUP, with a view to the conclusion of an alliance between Bulgaria and the Ottoman Empire. ${ }^{89}$ Evidently, this amounted to a reprise of the discussions which Shopov had held with the CUP immediately prior to the declaration of independence. It is possible that the CUP was tempted: Kâmil Pasha told Lowther that the CUP appeared to favour a Bulgarian alliance, but added that for his own part he was reluctant to enter into any discussion of this issue until all questions arising out of the declaration of independence had been resolved. ${ }^{90}$

There remained the question of Bulgaria's demobilization. As early as 17 October, Paprikov had told the British Minister at Sofia that Bulgaria would stand down her forces if the Porte would do likewise, and the Russians soon indicated that they would prefer any demobilization to be mutual. ${ }^{91}$ The Porte remained cautious: from London, Rifat Pasha, Ottoman 
Ambassador there, counselled against placing faith in Bulgarian guarantees. ${ }^{92}$ Equally important, the Porte's belated counter-mobilization was now in full swing, with large numbers of reservists being transferred to the Bulgarian frontier from Ottoman Asia, and the military balance was beginning to shift in the Empire's favour. ${ }^{93}$ The British proved reluctant to press the Porte too hard on this issue, despite Russian promptings: Lowther pointed to the danger of 'reactionary' outbreaks against the new regime, particularly in the capital, and suggested that the Porte's military precautions were justified on these grounds alone. ${ }^{94}$ Not until the beginning of November, after the Bulgarians had demobilised some 50,000 troops, did Britain advise the Porte to respond in kind. This advice was promptly taken.95

In the meantime the Grand Vizier had initiated steps to enhance the Ottoman Empire's military security against Bulgaria through understandings with the other Balkan states. It appears that as early as 2 October, before Prince Ferdinand's declaration of independence, the Porte had approached the governments of Romania, Serbia and Greece with offers of military alliances. As early as 7 October, Kâmil Pasha was able to report to the cabinet that Serbia's response had been welcoming, that the reaction of Greece had been non-committal, but that Romania, a long-standing ally of Austria-Hungary, had returned a clear refusal. ${ }^{96}$ Evidently, the Grand Vizier's immediate concern was to enhance the Empire's security against the threat of an early Bulgarian attack, but there is also evidence that he entertained longer-term conceptions. In a letter to Gabriel Noradonghian, the Minister of Public Works, Kâmil Pasha reiterated his view, already expressed before the revolution, that a war between the Ottoman Empire and Bulgaria was sooner or later inevitable, and indicated that he would regard an alliance with Romania, Serbia and Greece as having offensive as well as defensive implications. He envisaged that the alliance should run for a period of three years, during which time it would serve to insure the Empire against Bulgarian aggression. At the end of three years, however, the Empire should be strong enough to launch an offensive war against Bulgaria, if need be, unilaterally, with two war aims in view: firstly, to destroy at source Bulgaria's capacity to threaten the Empire in Macedonia, and secondly once more to detach Eastern Rumelia from Bulgaria. ${ }^{97}$

The Grand Vizier's proposal to separate Eastern Rumelia from Bulgaria was particularly striking, and appears to have been seriously meant: as will be seen, both the Porte and the CUP were to raise the idea of such a separation in their discussions with the Powers, and to suggest that it might be achieved by diplomatic means. There can be little doubt that their fundamental concern was to enhance the Empire's military security by transforming Eastern Rumelia into a demilitarised buffer-state: as Kâmil 
Pasha subsequently explained to Lowther, as long as Bulgaria remained in possession of Eastern Rumelia, the Empire would face the heavy burden of maintaining large forces on its frontier. ${ }^{98}$

The Porte promptly drew up draft conventions for discussion with Serbia, Romania and Greece. The draft convention with Serbia had a number of peculiarities, and is discussed below. The conventions with Greece and Romania, however, were almost identical: the sole difference was that the convention with Greece was to run for five years, and that with Romania for three. ${ }^{99}$ The available documentation does not explain the reasons for this difference. These conventions with Greece and Romania each stipulated that the contracting parties should engage to make common cause in every war, offensive or defensive, which any of them would find necessary to wage, but added that no party to either convention could open hostilities without having previous consultation. The draft conventions also stipulated that, should an attack upon one of the contracting parties be feared, the contracting parties should act in perfect accord in all military matters, and that each party should make military preparations in accordance with the spirit of the agreement. As the conventions had an offensive character, too, it was stipulated that each party should profit equally from all advantages and territorial gains resulting from a successful war. Finally it was stipulated that absolute secrecy should be observed with regard to the conventions. ${ }^{100}$

In practice, however, the Grand Vizier's project for a grand antiBulgarian alliance embracing all the other Balkan states ran out of steam rather rapidly. As noted, the Romanians had rebuffed his initial approach, and it remains unclear whether serious negotiations with Bucharest were ever begun. With Greece, on the other hand, relations were quickly overshadowed by a local crisis in Crete, an autonomous province of the Empire which had long since ceased to be under the Porte's effective control: on 7 October, taking its cue from the annexation of BosniaHerzegovina and the Bulgarian declaration of independence, the Cretan provincial assembly proclaimed the island's union with Greece. ${ }^{101}$ However, both countries were at pains to minimize the affair. The Greek Minister to the Porte reported home that the CUP and the Turkish press were ignoring the Cretan issue, and had taken up a very friendly attitude. The Greek side apparently responded in kind. ${ }^{102}$ Indeed, on 11 October the CUP confidentially informed the Greek Consul at Salonica that, war with Bulgaria now seeming unavoidable, the CUP had decided to arm the population, but that, as there were not enough rifles to go round, they would be grateful if the Greek government would supply them with some. ${ }^{103}$

Also on 11 October, the Ottoman Minister to Athens was instructed ask Greece to associate herself with the Ottoman protest against the violation by 
Bulgaria and Austria-Hungary of the Treaty of Berlin. When the Greek Foreign Minister remarked that such a move by Athens would be the first step in the direction of hostility towards Bulgaria, and asked whether he should take this request as an open invitation to an alliance, the Porte's representative admitted that he himself regarded the matter in that light. ${ }^{104}$ The official Greek reply to the Porte's overture emphasized that any association with the Ottoman protest would be tantamount to open hostility to Bulgaria, and the beginning of an effective common action with the Porte. The Greek government added that, despite all that, they were 'désireux, non seulement d'entretenir les meilleures relations amicales avec l'Empire voisin, mais de voir aussi s'établir entre les deux pays le rapprochement le plus étroit', and asked to know on what basis such a common action might be founded. ${ }^{105}$

It is possible that this Greek reply opened the way to further exchanges, perhaps involving some discussion of the Porte's projected military convention, but the available sources furnish no details. Before long, however, there were signs that the Ottoman side was drawing back. When the Greek Minister at Constantinople approached the Grand Vizier on 11 November to propose steps towards a closer understanding, he was fobbed off by Kâmil Pasha with the remark that the Greeks had better wait until the Cretan question got out of the way. ${ }^{106}$ Probably, the British Minister to Athens was correct in his assessment that conditions had changed since the idea of an alliance was first mooted, as the danger of war between the Ottoman Empire and Bulgaria was now over. The Greek Prime Minister himself conceded that the grounds for an alliance had now been diminished, although the necessity for closer co-operation and a better understanding was as urgent as ever. ${ }^{107}$ At all events, it seems clear that no Ottoman-Greek treaty was finalized or signed.

There remained the possibility of an alliance with Serbia and Montenegro. As already noted, the Serbs had returned a clearly positive response to Kâmil Pasha's overtures at the beginning of October, and the Ottoman Legation in Belgrade had been the object of several popular demonstrations of support. ${ }^{108}$ This was scarcely surprising, for Serbia and Montenegro both had long-standing territorial aspirations in Bosnia and Herzegovina, whose population was in good part ethnically Serb, and both viewed the Austro-Hungarian annexation as a direct blow to their national interests. In any case, relations between Serbia and Austria-Hungary were poor: since 1906 the two states had been engaged in a customs war. ${ }^{109}$ However, the opening of alliance negotiations between Constantinople and Belgrade was delayed, since Serbia wished first of all to reach a formal agreement with Montenegro. A Serb-Montenegrin military convention was signed on 24 October: ${ }^{110}$ though its terms were secret, the Serbs went out of 
their way to assure the Porte that it was in no way directed against the Ottoman Empire, and indeed, the Ottoman Minister to Serbia, Azarian Efendi, was the only foreign representative invited to the banquet given by the Serbian King on the occasion of the convention's signature. ${ }^{111}$

The signature of the Serb-Montenegrin convention opened the way to alliance negotiations between these two Balkan states and the Ottoman Empire in November. Given that the Porte had failed to win over Romania, and that it was soon to lose interest in the possibility of an understanding with Greece, it is worth asking why it should have continued to pursue an alliance with Serbia and Montenegro. The answer would appear to lie partly in the hope of bringing pressure to bear upon Austria-Hungary, but partly, too, in the Porte's fear, already expressed to the British, that Serbia and Montenegro might be tempted to demand compensation for the annexation of Bosnia and Herzegovina at Ottoman expense. No doubt this fear was further stimulated by the knowledge that Serbia and Montenegro enjoyed close relations with Russia. This points to an undeclared consideration behind the Grand Vizier's policy of rapprochement with the Balkan states: namely, a concern to keep the Balkan states in play, and to dissuade them from entering into commitments or combinations which might threaten Ottoman interests.

At the beginning of November, the Serbian government despatched a special envoy, Novaković, to Constantinople to negotiate an alliance with the Porte; ${ }^{112}$ Novaković was followed by a Montenegrin delegate, Vuković. ${ }^{113}$ Kâmil Pasha promptly showed Novaković the draft of an 'alliance défensive'. This stated that Serbia and the Ottoman Empire, animated by the desire to safeguard their respective territorial possessions against all eventual aggressions, had decided to conclude 'une convention spéciale défensive'. ${ }^{114}$ According to the original text, the Ottoman Empire would be expected to use its good offices with the Great Powers, as well as with Austria-Hungary, in the case that an attack by the Dual Monarchy upon Serbia were threatened, in order to prevent a final 'rupture' between these two states. Should the Porte's efforts fail to stop the war, and should a Great Power (by implication, Russia) indicate its desire to make common cause against the Dual Monarchy, the Ottoman government would not hesitate to offer Serbia military assistance. However, it was made clear that Serbia was under no circumstances to declare war upon Austria-Hungary without having previously informed the Porte and obtained its consent. ${ }^{115}$ With regard to Bulgaria, it was agreed that in the event of an attack upon either party, or of provocation by Sofia of a nature intended to disturb the peace in the Balkans, both sides were to mobilise and dispatch sufficient number of troops to defend each other's territory, and that the commanders of their respective armies were to concert their military operations. ${ }^{116}$ While, on the 
one hand, it was stipulated that the contracting parties would designate through a special convention the forces that each side was to deploy against the common enemy, the Empire and Serbia were at once to engage, should such a contingency prove unavoidable, to mobilize all the land and naval forces at their disposal from the conclusion of the convention onwards. ${ }^{117}$ In addition, the two governments should bind themselves not to do anything which might provoke hostilities without their mutual consent, and to act in full accord during the negotiations which would, following a victorious campaign, lead to a peace treaty. ${ }^{118}$ Finally, the convention stated clearly that the treaty would remain secret. ${ }^{119}$

This draft convention shed a revealing light on the Porte's view of its own interests. The strongest provisions were directed against Bulgaria; Serbia was offered military support against Austria-Hungary only in the event of Russian intervention; and there was no mention of BosniaHerzegovina. Not surprisingly, the Serbs demanded amendments. They proposed that the contracting parties give the utmost importance to the annexation of Bosnia and Herzegovina, and make every effort to find a solution satisfactory to the people of Bosnia-Herzegovina, as well as to Serbia and the Empire, and that, should all their endeavours fail to procure this result, the Porte would undertake to recognize Austro-Hungarian sovereignty over the two provinces only on condition that a strip of territory contiguous to Serbia and Montenegro were ceded to the latter states, either directly or through Ottoman mediation. In addition, the Serbs also suggested that the scope of the convention should cover Ottoman possessions in the Balkans only, as Serbia could not prove useful in defending the Porte's far-flung territories in Asia and Africa. ${ }^{120}$ The Grand Vizier apparently received the Serbian counter-proposals without initial objections, and allegedly even said that the Porte would never recognise the annexation, and would demand autonomy for Bosnia and Herzegovina. ${ }^{121}$ However, in return for acceptance of Belgrade's amendments, Kâmil Pasha soon came up with a further suggestion to the effect that 'any territory conquered by the allies after a victorious campaign against Bulgaria shall be divided in such a manner that Turkey shall obtain the eastern and Serbia the western portion', and that 'in case a war indemnity is obtained, it shall be divided equally between the two countries', a proposal which soon created a deadlock. Fearing that the Grand Vizier's additional clause implied aggressive intentions towards Bulgaria, the Serbian government thought of appealing to Britain to exert her influence with the Porte. ${ }^{122}$ However, second thoughts suggested that the Porte might regard any intervention by the British Ambassador at Constantinople as a breach of confidence, and the Serbs postponed their appeal. As an alternative means of breaking the deadlock, the Serbs put forward a new formula: 
Turkey on her part will take into account the wishes of Servia in regard to Bosnia and Herzegovina, and will accept no solution of the status of these provinces which does not either safeguard the fate of the Servian population there or afford territorial compensation to Servia and Montenegro. ${ }^{123}$

The Serbs and the Montenegrins remained anxious for an agreement with the Ottoman Empire. They feared that, if the negotiations failed, Serbia would be left facing a hostile Bulgaria on the one side, and an unfriendly Dual Monarchy on the other. ${ }^{124}$ In a bid for further negotiations, Spalaiković, Permanent Under-Secretary in the Serbian Foreign Ministry was sent out to Constantinople, and meanwhile Novaković was instructed to make a declaration affirming the community of interests between the two countries. ${ }^{125}$

However, none of these efforts was likely to budge the Grand Vizier. ${ }^{126}$ The negotiations clearly demonstrated that, while the interests of the Ottoman Empire and Serbia were not opposed, they were divergent. For Serbia, and also for its partner Montenegro, the issue of Austria-Hungary's annexation of Bosnia-Herzegovina had absolute priority. For the Porte, by contrast, this was a secondary issue; whether in the short or the long term, the Ottoman Empire's overriding concern was the military threat posed by Bulgaria. In addition, the tactical considerations which had led the Porte to pursue an understanding with Serbia were losing force. The threat of war with Bulgaria had clearly receded, and as early as 12 November Tevfik Pasha had admitted to Lowther that the Porte had been conducting the negotiations with Serbia half-heartedly. ${ }^{127}$ In addition, the Entente Powers had by now assured the Porte that there could be no question of compensating Serbia and Montenegro at its expense. Finally, it had become obvious by December that the Porte's demands for pecuniary compensation from Austria-Hungary and Bulgaria would receive the backing of several Powers. In these circumstances, the Grand Vizier could afford to give up the negotiations with Serbia and Montenegro, on the pretext that the latter were not able to sign an alliance of a defensive and offensive nature, that some indiscretions had been committed at Belgrade, and that, as a result, several Powers had become aware of what had been taking place. ${ }^{128}$

The Porte's negotiations with Serbia, as earlier with Greece and Romania, had been undertaken on its own initiative, without prompting from the Entente Powers. However, the Entente Powers were broadly aware of what had been going on. The British were initially somewhat sceptical: they feared that a system of offensive alliances might provoke a war, ${ }^{129}$ or at least, that it would push Bulgaria and Romania into the arms of the Dual Monarchy, thereby creating a dangerous polarization in the Balkan 
peninsula. ${ }^{130}$ The British preferred to see a system of defensive arrangements between the Balkan states, from which Bulgaria should not be excluded, and which might then serve to check the Dual Monarchy's influence in the Balkan peninsula. ${ }^{131}$ This view was endorsed by the French, ${ }^{132}$ who joined the British in urging it upon a CUP delegation which visited Paris and London in November. ${ }^{133}$ Not that the British were especially optimistic that an alliance such as they advocated would be achieved; by the end of the year Hardinge had privately admitted that the principal obstacles were the 'inveterate jealousy' among the small Balkan states and 'the secret desire of each of them to eat up Turkey'. ${ }^{134}$

The Russians, too, were warming up to the idea of a general Balkan alliance under the patronage of the Entente. As a counter to Izvolsky's discredited policy of partnership with Austria-Hungary on the basis of mutual compensations, Charykov and the Prime Minister Stolypin floated the idea of a 'Turco-Slavic bloc' in the Balkans, a project which enjoyed enthusiastic support in sections of the Russian press and public opinion. Although Izvolsky never took the idea seriously, ${ }^{135}$ public pressure forced him to take steps in that direction, and in a speech to the Duma, on 25 December he declared that 'Bulgaria, Serbia and Montenegro must become imbued with the consciousness of the necessity of moral and political union. Russia's aim is to bring these states together and to combine them with Turkey, through means of common interest for the defence of their national and economic independence.' ${ }^{136}$ These sentiments appear to have found no echo at the Porte, which had now abandoned its search for understandings with the Balkan states.

In the meantime, there were hopes, at the beginning of November particularly after mutual demobilization, that Ottoman-Bulgarian relations might lead to an early settlement. The Bulgarian government had despatched its Minister of Trade and Agriculture, Andrey Lyapchev, to Constantinople for formal talks, and empowered him to offer financial compensation in return for recognition of Bulgaria's independence. In principle, the Ottoman government was ready to settle on these terms. From the start, the Porte had indicated that it considered itself entitled to make a number of financial claims upon the basis of international treaties ${ }^{137}$ and Kâmil Pasha had quickly instructed the Minister of Finance and Public Works to enlist the co-operation of the Public Debt Administration in determining how much Bulgaria might be held to owe the Ottoman Empire. ${ }^{138}$ By the time the negotiations opened with Lyapchev, the Ottoman demands included: a) the capitalization of the Eastern Rumelian tribute, b) the capitalization of the Bulgarian tribute, which had never been paid, c) Bulgaria's assumption of a share of the Ottoman Public Debt, d) compensation for the nationalization of the Eastern Rumelian railways. As 
all these claims could be supported by stipulations in the relevant treaties, it appeared that the Porte could demand up to $£ T .28,000,000$, a sum well beyond Bulgaria's ability to pay. ${ }^{139}$ Although Kâmil Pasha privately assured Lowther that he was prepared to reduce this demand to $T £ 10,000,000,{ }^{140}$ he, nonetheless, emphasized that he had sound political reasons for wishing to burden Bulgaria with as large an indemnity as possible: only thus could she be prevented from spending 'huge sums of money' on armaments, and threatening the Empire in Macedonia. Once more, the Grand Vizier revealed that his overriding preoccupation in relation to Bulgaria was security, not rights or money.

The problem, as Refik Bey had already warned, was that the Bulgarian government took the view that independence was to be won with 'blood', not purchased with 'money'. ${ }^{141}$ Lyapchev was prepared to offer compensation for the Eastern Rumelian tribute, and also for the railways, but he adamantly refused to hear of the Bulgarian tribute, or to assume a share of the Ottoman Public Debt. The maximum sum he was prepared to offer was 82,000,000 francs (T£ 3,200,000). ${ }^{142}$ He also attempted to raise other issues, demanding that the Bulgarian Exarchate, the supreme leadership of the Bulgarian Orthodox Church, be maintained in Constantinople, and that the Ottoman government give written assurances of the well-being and protection of the Bulgarians in Macedonia. ${ }^{143}$ Refik Bey had earlier reported that these demands were made in order to strengthen the position of Malinov's government, and advised that none of these points should be discussed with Lyapchev since they had nothing to do with the Bulgarian declaration of independence. ${ }^{144}$

The Porte proved equally obdurate. It was in no mood to widen the scope of the negotiations; it complained that Lyapchev had been given insufficient powers ${ }^{145}$ it was encouraged by despatches from Refik Bey indicating that domestic opposition to the Bulgarian government's hostile policy towards the Ottoman Empire was growing; ${ }^{146}$ and finally it was also encouraged by Britain's declaration that Lyapchev's offer was too small. ${ }^{147}$ By the end of November, deadlock had been reached, and Lyapchev returned to Sofia; before leaving, he told the Powers' representatives in the Ottoman capital that $82,000,000$ francs remained his maximum offer, and that if the Porte contemplated obtaining a larger sum, it 'ought to go to Sofia to fetch it'. ${ }^{148}$ However, Lyapchev's withdrawal did not amount to a formal breaking-off of negotiations, and the Grand Vizier promptly wrote to Prince Ferdinand, assuring him of the Porte's desire for agreement. He explained that he was quite aware that the Powers, when called upon to fix a sum to resolve the dispute, would take into account how much Bulgaria could reasonably be expected to pay, regardless of what the Porte could claim under several headings of international treaties. He hinted that if Bulgaria could go some 
way further than its initial offer of $82,000,000$ francs, a satisfactory settlement might be arranged. Kâmil Pasha added that an independent Bulgaria, deprived of the guarantees she had enjoyed when she was under the Ottoman suzerainty, would need the Porte's friendship more than ever. Finally, he emphasized that the Porte had no intention of resolving the dispute through war. ${ }^{149}$

At the same time, however, the CUP announced that its boycott of Austro-Hungarian goods had been extended to Bulgarian merchandise. The Porte apparently believed that it could afford to wait. For one thing, it enjoyed some support from the Powers. Though the British government had warned that the amount of compensation must be determined by Bulgaria's ability to pay rather than by the letter of the Empire's legal rights, it, nonetheless, insisted that Lyapchev's offer of $82,000,000$ francs was inadequate. Its own calculations suggested that Bulgaria should be requested to pay between $T £ 5,000,000$ and $T £ 10,000,000$, that is, between $125,000,000$ and $250,000,000$ francs. ${ }^{150}$ The French, with a considerable detailed knowledge of Ottoman and Bulgarian finances, came up with a similar estimate. ${ }^{151}$

For another thing, Refik Bey continued to send optimistic reports from Sofia. These stated that there existed considerable opposition within the Bulgarian parliament, which criticized the Malinov government for having acted with unnecessary haste in declaring independence at a time when the CUP was displaying an unprecedentedly friendly attitude towards Sofia and the Bulgarians in Macedonia, ${ }^{152}$ that the pro-Ottoman Allied Committee and other influential persons were stepping up their activities in favour of a rapprochement with the Porte, that Prince Ferdinand, disillusioned with the existing government's policy, had approached a prominent member of the Liberal Party, Panchev, about the replacement of Malinov's cabinet, and finally that Panchev, known to be friendly to the Ottoman Empire, had been making plans for a satisfactory agreement with the Porte. ${ }^{153}$

In the event, however, these optimistic predictions were not borne out, and by mid-December there were signs of renewed tension in relations between Constantinople and Sofia. The immediate pretext was an allegedly slighting reference to Prince Ferdinand in the speech with which Sultan Abdülhamid opened the new Ottoman Parliament on 17 December. ${ }^{154}$ This prompted the Bulgarian government to issue a strong note of protest to the Porte, and also to the Powers. The note asserted that the Bulgarian declaration of independence was not intended as a hostile act towards the Ottoman Empire, and it complained that the Porte's policy towards Sofia was ambiguous. The trade boycott organized against Bulgarian goods by the CUP after Lyapchev's departure from Constantinople was mentioned as a clear example of the Porte's ambiguity and hostility. ${ }^{155}$ Sofia urged the 
Powers to take steps to force the Porte to withdraw its 'extravagant' claims. ${ }^{156}$ On 26 December the Bulgarian government made a further protest to Refik Bey, this time at the continuation of the boycott, in which, having enumerated several cases where Bulgarian goods had been prevented from being brought to market or from entering Ottoman territory, the Porte was requested to take measures to stop the boycott. Otherwise, the Bulgarian government would hold the Porte responsible. ${ }^{157}$ By December OttomanBulgarian negotiations had bogged down.

Though the Porte attempted to restart its stalled negotiations with Bulgaria, nothing concrete came out during December, and the tension between the two countries was rising. ${ }^{158}$ To break the deadlock, Kâmil Pasha formally invited, on 7 January, the Bulgarian government to send Lyapchev back to Constantinople. In the meantime, Austria-Hungary had agreed to pay pecuniary indemnity to the Porte for the annexation of Bosnia and Herzegovina, which, it was thought, would in turn open the way for a similar agreement with Bulgaria. From Sofia, Refik Bey reported that the Bulgarians were likely to accede to this request, ${ }^{159}$ but in the event the Bulgarian government chose to turn instead to the Powers, explaining to them that it would be pointless to renew negotiations with the Porte without a prior understanding as to the subjects of discussion. Specifically, the Bulgarians warned that they could not raise their offer of financial compensation above the $82,000,000$ francs already offered, but added that they would be prepared to discuss an entente or alliance with the Ottoman Empire. ${ }^{160}$ The Grand Vizier conceded that the latter suggestion 'mérite de fixer attention', but stressed that Bulgaria must first show a conciliatory spirit by raising her financial offer: once normal relations had been restored, the Porte would be quite willing to consider an alliance with Bulgaria. ${ }^{161}$ The British broadly endorsed the Grand Vizier's line, warning the Bulgarians that they must raise their offer of financial compensation, ${ }^{162}$ and on 11 January Grey suggested that the moment had arrived for the Entente Powers, perhaps supported by Italy, to inform Sofia that a sum of $125,000,000$ francs was the minimum acceptable. ${ }^{163}$ However, Izvolsky quickly objected that the figure was too high: to demand more than $100,000,000$ francs would risk pushing Bulgaria 'into the arms of Austria and Germany'. ${ }^{164}$

In the meantime, however, the Grand Vizier had come up with a new scheme of his own: if the Bulgarians were unwilling to increase their offer of financial compensation, they might additionally agree to a small rectification of the frontier between the Ottoman Empire and the former Eastern Rumelia. It appears that the Grand Vizier rested his legal case upon the agreement for a frontier revision drawn up in 1886, following the Eastern Rumelia's unification with Bulgaria, and which, he claimed, had 
never been fully implemented. Practically, he envisaged the cession of a small number of Muslim villages near Cisr-i Mustafa Paşa, whose return to Ottoman control would facilitate communications between Kurcaali and Adrianople. Kâmil Pasha had mentioned the possibility of such a border rectification to Pallavicini in passing on 12 January; ${ }^{165}$ he subsequently also mentioned it to the British and Russian Ambassadors, neither of whom appears to have raised any objection. ${ }^{166}$

The Grand Vizier communicated his proposal to the Bulgarian government officially in late December, and in so doing fell into a trap of his own making. ${ }^{167}$ Whether because they genuinely feared that the Ottoman government was intending to make substantial territorial demands, and perhaps even revive its earlier demand for Eastern Rumelia's separation from Bulgaria, or whether because they saw an opportunity to discredit the Porte in the eyes of the Powers, the Bulgarians chose to treat the Grand Vizier's proposal as a hostile provocation, and responded by mobilizing the 8th Division of their army, based at Stara Zagora in Eastern Rumelia. They then issued a note to the Powers, accusing the Porte of making military preparations to capture strategic positions on the frontier. There is no evidence to support this accusation in Ottoman records; nonetheless, the result was a fresh Ottoman-Bulgarian war scare, for which the Porte was neither politically nor militarily prepared.

The Bulgarian mobilization came as a complete surprise to Kâmil Pasha's cabinet. Although there was information at the Porte's disposal indicating that the Bulgarian Army had been stockpiling provisions, ${ }^{168}$ it does not seem to have been taken seriously. But, as soon as the mobilization commenced, the Ottoman Commission and military personnel in and around Bulgaria began to inundate the Porte with reports on troop movements and other military preparations. ${ }^{169}$ The Ottoman Chief of Staff at once warned the Grand Vizier that the Empire was in no position to risk armed conflict with Bulgaria. He conceded that it was not yet clear whether the Bulgarians intended anything 'serious', but he pointed out that the Bulgarian army was capable of mobilizing much more rapidly than the Ottoman army, and that however limited the military measures which Sofia had taken, they nonetheless placed the Empire at a major strategic disadvantage, exposing it to the risk of a Bulgarian first strike. He proposed that a counter-mobilization be ordered, but emphasized that the Empire had nothing to gain by war: it would take a full three years to bring the Ottoman army, and European diplomatic opinion, to a point where the Empire might contemplate war with Bulgaria with a prospect of decisive victory and real political gains. In present circumstances, however, even a successful campaign was most unlikely to produce tangible advantages: defeat would mean disaster. 
It is, in all probability, within the bounds of possibilities, that even the Slav governments [Serbia and Montenegro] which have become disillusioned and offended due to the existing conflict with AustriaHungary would, following the Bulgarian invasion, also hasten to attack the Ottoman Empire in order to obtain the sort of territorial advantages they had sought to gain at the Dual Monarchy's expense from the Ottoman possessions, and it cannot be assumed that Greece would, in such a contingency, keep quiet and stay neutral. Thus it should be deemed certain that the whole situation will result in a disaster, unless Bulgaria and the other aforementioned governments are not prevented from pursuing aggressive policies. ${ }^{170}$

In practical terms, the Chief of Staff proposed two courses: an appeal should be made to the Great Powers for diplomatic assistance, and local alliances should be sought in the Balkans. He suggested that an entente, at least on a defensive basis, be signed with Rumania, and that some kind of military arrangement be concluded with Austria-Hungary with a view to restraining Serbia and Montenegro. ${ }^{171}$ The Chief of Staff's advice harmonized with Kâmil Pasha's own inclinations. In a telegram to London, the Grand Vizier instructed Rifat Pasha to impress on the British Foreign Office that his government had conducted itself throughout in accordance with the Powers' advice, and sought a peaceful settlement with Bulgaria through negotiations. He professed no anxiety at the reported Bulgarian military preparations, but warned that any Bulgarian coup de main would provoke a general conflagration, with the other Balkan states being drawn in. He drew the British government's attention to reports that the Bulgarian authorities were distributing arms to civilians in frontier districts, thus creating the danger of clashes with civilians on the Ottoman side of the border. As to a solution of the independence dispute, he stressed that his offer to settle for compensation of $100,000,000$ francs, with a slight frontier rectification in addition, fell far short of the maximum claims to which the Porte felt theoretically entitled, and he revealed that he had already offered Sofia an alternative: immediate compensation of $100,000,000$ francs, with the question of the purchase of the Oriental Railways adjourned for future negotiation. Kâmil Pasha emphasized that Bulgaria's bellicose actions were producing a similarly bellicose reaction on the part of the Ottoman public opinion, and pressed the British government to take the lead in persuading the Powers to force Bulgaria to pay $125,000,000$ francs, a sum Grey had suggested all along. As a bait, Kâmil added that he would settle for a downpayment of $100,000,000$ francs, with the remainder to be paid later: he was confident that he could defend such an arrangement before the Ottoman parliament, provided that the Powers approved it. ${ }^{172}$ 
In the meantime the Ottoman government had ordered limited measures of counter-mobilization against Bulgaria. ${ }^{173}$ Nonetheless, the Grand Vizier remained anxious above all to avoid war, and continued to address the most urgent appeals for diplomatic intervention to the British government. ${ }^{174} \mathrm{He}$ assured Lowther that he would be prepared to accept the sum of $100,000,000$ francs from Bulgaria as an initial down-payment, on the understanding that Bulgaria should pay a further 25,000,000 francs as soon as she could afford it. ${ }^{175} \mathrm{He}$ then offered an alternative combination: Bulgaria should pay $100,000,000$ francs as an indemnity for her independence, and at a later stage, pay 25,000,000 francs as the purchase price of the Eastern Rumelian railways. Finally, he suggested that if Bulgaria were still unwilling to raise her offer above $82,000,000$ francs, the question of compensation might be submitted to the arbitration of the Powers. ${ }^{176}$ At the same time Kâmil Pasha informed Lowther that he had assured the Bulgarian government that the Porte had no intention of demanding territory or strategic points: its sole aim was to complete the work of frontier demarcation left unfinished in 1886, preferably in a form which would facilitate communications between the Ottoman district of Kircaali and Adrianople. ${ }^{177}$ These appeals proved effective: on 27 January Grey informed Lowther that he would seek to gather the support of the other Powers for the suggestion that they should jointly settle the amount of compensation which Bulgaria should pay to the Porte. ${ }^{178}$

In the event, however, Grey's proposal for international arbitration was immediately overtaken by a Russian initiative. On 29 January Izvolsky suggested to the British government that the Porte might be offered $125,000,000$ francs as compensation for Bulgaria's indepenence. ${ }^{179}$ However, he added that this sum need not be paid by Bulgaria directly; instead, Russia would waive, for a period of 15 years, the annual payments due to it from the Porte under the terms of the war indemnity imposed upon the Ottoman Empire following the Ottoman-Russian war of 1877-78. If in need of cash, the Porte might easily arrange with banks for the capitalization of these 15 annual payments representing a total sum of $125,000,000$ francs. As to Bulgaria, it would assume a total obligation towards Russia of $82,000,000$ francs in the form of a loan, to run for 50 or more years, for which Russia would charge a moderate rate of 4 or 4.5 per cent interest. The burden of the remaining 43,000,000 francs due to the Porte would be assumed by Russia itself. As Izvolsky admitted, the Bulgarians would get off lightly: they would pay no more than the $82,000,000$ francs they had held out for, and on considerably easier terms than they would have obtained had they been obliged to raise the sum through a normal commercial loan. ${ }^{180}$

Grey endorsed Izvolsky's proposal with alacrity, and promised to 
recommend it in Constantinople and in Sofia ${ }^{181}$ The Bulgarian government promptly announced its acceptance of the Russian scheme in principle, ${ }^{182}$ much to the annoyance of Aehrenthal, who took this as a major diplomatic setback, and promptly broke off his alliance negotiations with Sofia. The Porte, however, was by no means happy with the Russian proposal, and made plain its dissatisfaction to the British. In the first place, it was not officially approached by Russia until 5 February, long after it had learned of the proposal from other Powers. ${ }^{183}$ This led the Porte to suspect that Izvolsky's proposal might have hidden strings attached, possibly including a fresh attempt to open the Straits question. ${ }^{184}$ Nor was the Porte impressed with the contents of the Russian proposal. Kâmil Pasha warned Lowther that it would force Bulgaria into permanent dependence on Russia, and that Bulgaria would become the vanguard for a future Russian drive on Constantinople. He also complained that the mild terms imposed upon Bulgaria would leave it free to spend large sums on her army, forcing the Ottoman Empire in its turn to make heavy military outlays. ${ }^{185}$

The British government brushed all these objections aside, however, and insisted that the Porte should accept the Russian proposal. ${ }^{186}$ Writing to Lowther on 6 February, Hardinge made no bones about the British goverment's strong support for the Russian proposal. ${ }^{187}$ Faced with Britain's uncompromising attitude, the Porte had no choice but to give way, and on 5 February it accepted the Russian proposal in principle. At the same time, however, it indicated that it considered itself entitled to demand more ample compensation: specifically, Russia should agree to waive all the outstanding instalments of the war indemnity, not just 15 years' worth. The Porte noted that Bulgaria would pay no more than $82,000,000$ francs, but that several Powers had previously indicated that compensation should amount to as much as $120,000,000$ or $150,000,000$ francs. A figure in the latter range, the Porte added, would be equivalent to the capitalization of all the outstanding instalments of the war indemnity. ${ }^{188}$ Money was evidently not the only consideration. Speaking in his personal capacity, Rifat Pasha explained to Grey that the Grand Vizier's task of reconciling public opinion in the Empire to the settlement of the Bulgarian question, as well as to the results of the negotiations with Austria-Hungary, would be made much easier if what remained as a kind of yearly Ottoman tribute to Russia were entirely remitted, for it would produce an excellent effect morally and politically. Rifat Pasha suggested that Russia should give her consent to a loan being raised on the whole amount of the indemnity, and that the Porte should retain 125,000,000 francs from the amount thus realised, while Russia should receive the remainder. ${ }^{189}$ This time Grey's response was sympathetic, though he made no definite commitment.

In the meantime the Porte had also commenced negotiations with Russia 
on the details of an arrangement to regulate the financial compensation to be paid for Bulgaria's independence. A delegation headed by Rifat Pasha, newly appointed foreign minister, arrived in St. Petersburg on 4 March. The essentials of the settlement were not in dispute: Russia would compensate the Porte by waiving part of the War Indemnity, and the Bulgarians would in turn compensate Russia. However, the Porte remained eager to be freed from the War Indemnity in its entirety, and this prompted Izvolsky to bring forward two essentially political conditions. ${ }^{190}$ In the first place, he suggested that the Porte should accept the good offices of Britain and Russia in resolving a long-running Ottoman-Iranian boundary dispute, in which the Russians had a declared interest. In the second, he proposed that the Porte should offer a concession for the construction of a railway linking Serbia with the Adriatic, possibly via the Sanjak of Novi Bazar. Rifat Pasha declared himself willing to consider a settlement of the border dispute with Iran, but refused to be drawn into any engagement in respect of an Adriatic railway: he would do no more than promise to examine the scheme in a friendly spirit at a later date. ${ }^{191}$ The financial aspects of an agreement to deal with that portion of the War Indemnity not counted as part of the Porte's compensation for Bulgaria's independence provoked further haggling, in which the British Ambassador to St. Petersburg, Nicolson, offered Rifat Pasha some support. In the event, a compromise was reached: it was agreed that the Porte might offer Russia a down-payment of $125,000,000$ francs, to be raised by means of a loan, in lieu of its annual payments for the next 30 to 35 years. Once these 30 or so years had expired, the operation would be repeated, enabling the Porte to liquidate its remaining obligations under the War Indemnity with one single instalment. Nicolson endorsed the compromise, assuring Rifat Pasha that in 30 years or so, so much might happen, and even the indemnity might be forgotten'. Rifat Pasha signed the definitive Ottoman-Russian protocol on 16 March. ${ }^{192}$

The Ottoman-Russian protocol was essentially a financial arrangement, and left a number of political issues to be resolved by direct negotiations between the Ottoman Empire and Bulgaria: the questions of Muslim communities and pious foundations in Bulgaria, of posts and telegraphs, the administration of lighthouses and quarantine regulations. ${ }^{193}$ The Porte was eager for a quick settlement, possibly because it had obtained a copy of an alleged Russo-Bulgarian treaty of alliance; ${ }^{194}$ it quickly asked Sofia to send a delegation to Constantinople to negotiate. ${ }^{195}$ Sofia replied that it would send Lyapchev. ${ }^{196}$ The Porte appointed Rifat Pasha and Noradonghian Efendi to represent it in the negotiations. ${ }^{197}$

Lyapchev's talks with the Porte began against a background of mounting tension between the CUP and its domestic opponents, and no conclusion had been reached by the time of the ' 31 March Incident' - the 
Constantinople uprising of 13 April which led to the temporary ejection of the CUP from the capital. The newly appointed Grand Vizier, Hüseyin Hilmi Pasha's cabinet fell, and was replaced by one headed by Tevfik Pasha, in which, however, Rifat Pasha retained his previous post as Minister of Foreign Affairs. ${ }^{198}$ The Bulgarians quickly sought to turn this situation to their advantage. The Powers were postponing their formal recognition of Bulgaria's independence pending a settlement between Sofia and the Porte: arguing that this latest outbreak of internal instability in the Ottoman Empire threatened to jeopardise the prospects for settlement, Sofia demanded that the Powers recognise Bulgaria's independence immediately. ${ }^{199}$ The Bulgarian representative in St Petersburg threatened that otherwise, Bulgaria would mobilize and declare war upon the Ottoman Empire. Izvolsky allowed himself to be carried away by these arguments, and urged Paris and London to agree to early recognition. ${ }^{200}$ The French endorsed his proposal, ${ }^{201}$ but the British remained firm, dismissing Bulgaria's threats as 'bluff', ${ }^{202}$ and insisting that there could be no recognition of Bulgaria's independence before the Porte had consented to it. ${ }^{203}$

Thanks in part to the efforts of Lowther, Rifat Pasha and Lyapchev settled the terms of an Ottoman-Bulgarian protocol on 19 April; the Porte promised to secure early ratification by parliament. ${ }^{204}$ This agreement was reached against the background of a fast-changing political situation within the Ottoman Empire. Though ejected from the capital, the CUP had succeeded in rallying support in Macedonia, where units of III Army had been formed into an 'Army of Operations', under the command of Mahmud Şevket Pasha, ${ }^{205}$ with the intention of marching upon Constantinople to crush the 'counter-revolutionaries' and overthrow the 'illegal' cabinet of Tevfik Pasha. Alarmed, Lyapchev sent a copy of the 19 April protocol to Shopov at Salonica; Mahmud Şevket Pasha gave Shopov a categorical assurance that he would do all in his power to secure the ratification of the protocol, since both he and the CUP earnestly wished to improve relations with Bulgaria. ${ }^{206}$ The Army of Operations duly advanced upon Constantinople; before it entered the capital, the Ottoman Parliament convened under its auspices in the suburbs, under the new title of 'National Assembly'. On 23 April the National Assembly had its first sitting, and immediately ratified the Ottoman-Bulgarian protocol. On the following day the Army of Operations entered the capital, and put down the 'rebellion', restoring Hüseyin Hilmi Pasha's cabinet to office.

The significance of the Ottoman-Bulgarian protocol lay in the fact that it registered the Porte's de facto recognition of Bulgaria's independence. Otherwise, its contents were technical. It granted the Muslim population of Bulgaria religious freedom, and stipulated that 'the name of His Majesty the Sultan as the Khalife will continue to be read out in the praying places of 
the Muslims'. It also stipulated that the problems between the Bulgarian government and the Oriental Railway Company, arising out of Bulgaria's nationalization of the Eastern Rumelian railways should be resolved between Sofia and the Company. ${ }^{207}$ The protocol opened the way to international recognition of Bulgaria's independence. Russia was first to recognise Prince Ferdinand as 'Czar of the Bulgarians', and France followed suit. ${ }^{208}$ The Porte, however, continued to object to Ferdinand's choice of title, and for the same reasons which it had adduced in October 1908; not until May 1909 did the Porte formally recognize Bulgaria's independence de jure, and even then, it insisted upon addressing Ferdinand as no more than 'Roi de Bulgarie'. ${ }^{209}$

From the Ottoman Empire's point of view Bulgaria's independence crisis entailed direct threats to Ottoman security. Naturally enough, for the duration of the crisis, Ottoman attention focused primarily on Bulgarian military movements. Like other governments, the Ottoman Empire was taken by surprise by Bulgaria's declaration of independence. Its unpreparedness was reinforced by the fact that it possessed a new regime which had just come to power as the result of a revolution, a regime, furthermore, which consisted of an uneasy coalition between the CUP, on the one hand, and a cabinet of old regime figures led by Kâmil Pasha, on the other. The new regime had had no time to formulate a clear foreign policy before the crisis overtook it. Kâmil Pasha had brought to office a deep pessimism on the subject of the Empire's relations with Bulgaria. For its part, the CUP had brought with it an anti-Europeanism expressed in a determination to reassert the Empire's independence and dignity in the face of the European Great Powers, and perhaps, too, hopes of reaching a lasting accommodation with Bulgaria. But none of these amounted to a definite diplomatic strategy.

Faced by the outbreak of the crisis, however, Kâmil Pasha was quick to define his priorities. He clearly identified Bulgaria's declaration of independence as an issue more vital from the Empire's point of view than Austria-Hungary's annexation of Bosnia and Herzegovina. This was not because the independence issue possessed greater intrinsic importance, but because Kâmil Pasha had long since identified Bulgarian expansionism as one of the principal threats to Ottoman security. He strove to use the crisis to weaken Bulgaria, by attempting to construct alliances with the other Balkan states, by floating the idea of demilitarising Eastern Rumelia, and by demanding financial compensation so large as to cripple Sofia's capacity for military expenditures. At the back of his mind was the conviction that a war with Bulgaria was inevitable, though not immediately: the Empire needed some three years to prepare. 
In sum, Kâmil Pasha pursued a diplomacy of limited aims. He sought to contain the crisis, to forestall potentially hostile demands that other Powers and the Balkan states might make, and to enhance the Empire's long-term security against Bulgaria. In contrast, the CUP's approach to the annexation crisis appears to have been both more ambitious and more hesitant. Unlike Kâmil Pasha, the CUP did talk of alliances, with Austria-Hungary, on the one hand, and with Britain and France, on the other ${ }^{210}$ It also seems likely that the CUP entertained some hopes of a formal alliance with Bulgaria. However, the fact that all these options were explored indiscriminately, and almost simultaneously, is an indication that the CUP was never finally able to make up its mind as to the diplomatic strategy it should follow. It is possible to attribute this hesitancy to the CUP's anti-Europeanism, and also to its lack of any strong preference for any of the Powers. But it is also possible to discern other factors behind the CUP's unsuccessful excursions into grand policy: an inability to fully comprehend the dynamics of Great Power diplomacy, and a marked tendency to overestimate the Ottoman Empire's diplomatic strength. One consequence, it may be suggested, was to render the CUP a less effective influence upon the Empire's diplomacy during the Bulgarian independence crisis than might have been anticipated: the policies pursued from the outbreak of the crisis through to the settlement of principles reached in February and March 1909 were essentially those of Kâmil Pasha. This is not to deny that the CUP made a distinctive contribution to Ottoman policy. All in all, the outcome of the crisis was a success for the Ottoman Empire. Though Kâmil Pasha's Balkan Alliance scheme fell through, it had at least helped to prevent the Balkan states from combining against the Empire. However, there were also some losses. Kâmil Pasha's hopes of fundamentally weakening Bulgaria had been disappointed: the proposed Balkan alliance had come to nothing, the Entente Powers would not hear of territorial or military restrictions upon Bulgaria, and the agreed compensation for independence was not sufficient to curb Bulgaria's military ambitions. The problems of Ottoman-Bulgarian relations, and of the Empire's political and military security in the Balkan peninsula, remained unresolved.

\section{NOTES}

1. For a general understanding of Abdülhamid II's foreign policies, see, D. Akarl, The Problems of External Pressures, Power Struggles and Budgetary Deficits in Ottoman Politics under Abdülhamid II (1876-1908): Origins and Solutions, (Unpublished Ph.D. thesis, Princeton, 1976). See, also, F.A.K. Yasamee, Ottoman Diplomacy: Abdülhamid II and the Great Powers, 1878-1888 (Istanbul, 1996).

2. For a general appraisal of this period, see, L.S. Stavrianos, The Balkans since 1453 (Holt, Rinehart and Winston, New York, Chicago, 1965), Part IV and V. See, also, B. Jelavich, 
History of the Balkans. Eighteenth and Nineteenth Centuries (Cambridge University Press, 1983), I., pp.378-9.

3. In 1880 the Ottoman Empire had a population of 21 millions, while all the other Balkan states put together (Romania, Greece, Bulgaria, Serbia and Montenegro) possessed only a population of less than 11 millions. By 1914, however, the demographic figures had changed considerably. While the Ottoman population decreased to 20 millions, the population of the Balkan states had increased to 22 millions. See, E.J. Hobsbawm, The Age of Empire, 1875-1914 (London, 1987), p.342, table 1. Although this decline in Ottoman population and increase in that of the Balkan states was partly due to the Empire's territorial losses, it was clear that the populations of the Balkan states were rising rapidly. For details of the Ottoman population from 1880 to 1914, see K.H. Karpat, Ottoman Population, 1830-1914. Demographic and Social Characteristics (The University of Wisconsin Press, 1985), pp.18-44, 107-90. This population increase continued in 1930's in the Balkans. See, Stavrianos, op.cit., pp.594-7.

4. See H. Ünal, Ottoman Foreign Policy During the Bosnian Annexation Crisis, 1908-1909 (hereafter, Ottoman Foreign Policy) (Unpublished Ph.D. dissertation, University of Manchester, 1992), pp.27-8; B. Jelavich, History of the Balkans. Twentieth Century (Cambridge University Press, 1983), II., pp.440-1.

5. F. Adanır, Die Makedonische Frage: Ihre Enstehung und ihre Entwicklung bis 1908 (Wiesbaden, 1979) pp.100-3.

6. Adanir, op.cit., pp.88-99.

7. For IMRO, see, Adanir, op.cit., pp.20-209.

8. For details of the Bulgarian armed bands' activities against Ottoman rule throughout Macedonia and Ottoman reaction, see, (Binbaşı) Şemseddin, Tarihçe-i Devr-i İnklâb (Istanbul, 1324-1908), pp.43-51; Adanir, op.cit., pp.179-99; D. Dakin, The Greek Struggle in Macedonia, 1897-1913 (Thessaloniki, 1966), pp.92-106; T. Uzer, Makedonya'da Esskiyallk Tarihi ve Son Osmanl Yönetimi (Ankara, 1979), pp.140-60.

9. Ibid. See, also, for all the reform projects imposed upon the Ottoman Empire by the Great Powers and their consequences in Macedonia, A. Gül Tokay, Makedonya Sorunu: Jön Türk Ihtilalinin Kökenleri (1903-1908) (Istanbul, 1995).

10. H. Ünal, 'Abdülhamit Nasıl ve Ne Zaman Pes Etti?'(hereafter 'Abdülhamit Nasıl'), Tarih ve Toplum (Istanbul), Ekim (October) 1993, No.118, pp.43-44.

11. See T.S. Todorova and E.P. Statelova, Dokumenti po Obyavyavane na Nezavisimostta na Balgaria 1908 godine. Iz Tayniya Kabinet na Knyaz Ferdinand (Sofia, 1968), no.13.

12. Buchanan to Sir Edward Grey (British Foreign Secretary at the time), 1 August 1908, FO371/544,26786). Buchanan, however, expressed reservations about the whole matter. He thought that Kamil must have come up with such a proposal simply to test Bulgaria's attitude towards what was happening in Ottoman Macedonia. But he conceded that, in the event of Bulgaria's 'assistance' to the Sultan in defeating the Young Turks, he was to have granted Sofia full independence. See, for instance, Buchanan to Grey, 5 August 1908, FO371/545,27961.

13. See, for details, Documents diplomatiques français, 1871-1914 (Ministère des Affaires Etrangères, Commission de Publication des Documents Relatives aux Origines de la Guerre de 1914 - hereafter $D D F$ ), 2. série, XI, No.422, note 1, p.732.

14. Sir Gerald Lowther (British Ambassador at Constantinople) to Grey, 10 August 1908, FO371/545,28455.

15. See, H. Unal, 'Young Turk Assessments of International Politics, 1906-1909' (hereafter 'Young Turk Assessments', op.cit.) Middle Eastern Studies, Vol.32, No.2 (April 1996), pp.34-5.

16. Ünal, Ottoman Foreign Policy, op.cit., pp.69-70.

17. Yasamee, op.cit., pp.152-3, 219-20, 222-35.

18. H.K. Bayur, Sadrazam Kâmil Paşa. Siyasî Hayatı (Ankara, 1954), pp.232-4.

19. Başbakanlık Osmanlı Arşivleri, Yıldız Tasnifi, Yıldız Esas Evrakı, M. Kâmil Paşa Evrakına Ek (hereafter Y. Kâmil Paşa), 86/32,3136.

20. See, for these activities, Ünal, 'Young Turk Assessments', op.cit., pp.36-40.

21. T. Vlakhov, Krizata v Balgaro-Turskite Otnosheniya, 1895-1908 (Sofia, 1977), p.143. 
22. According to some Bulgarian press reports, at the outset of the Young Turk revolution the Young Turks even decided to erect monuments in various parts of Macedonia in memory of all the fallen Bulgarian chetniks [bandit leaders] who had fought against the previous regime. See, for instance, reports from Refik Bey, Deputy-Ottoman Imperial Commissioner at Sofia, in Bâb-1 Âli Evrak Odası, Eyâlet-i Mümtâze, Bulgaristan Evrakı (hereafter AMTZ), 169/57.

23. Austria-Hungary's Ambassador, Pallavicini, thought that the Ottoman Empire and Bulgaria were drawing close, and that a Balkan League under Ottoman leadership, and friendly to Vienna might be a practical proposition. See Pallavicini to Aehrenthal (Austria-Hungarian Foreign Minister), 12 August 1908, Österreich-Ungarns Aussenpolitik von der bosnischen Krise bis zum Kriegsausbruch 1914 (ed.) by L. Bittner and Uebersberger (Vienna, 1930) (hereafter $O U A$ ), I., no.34.

24. For CUP's relations with various Greek groups prior to the Young Turk revolution, see A.J. Panayotopulos, 'Early Relations between the Greeks and the Young Turks', Balkan Studies, XXI (Thessaloniki, 1980), pp.89-90. See, also, M. Ş. Bleda, Imparatorluğun Çöküşü (Istanbul, 1979), pp.23-5; Dakin, op.cit., pp.377-8.

25. Dakin, op.cit., pp.378-92.

26. There is a great deal of literature on the Bosnian annexation crisis. See, for instance, B.E. Schmitt, The Annexation of Bosnia, 1908-1909 (New York 1937); M. Nintchitch, La Crise bosniaque 1908-1909 et les Puissances européennes (Paris, 1937), 2 volumes; A.F. Pribram, Austria-Hungary and Great Britain, 1908-1914 (New York, 1951), pp.111-38; F.R. Bridge, From Sadowa to Sarajevo, 1841-1914: The Foreign Policy of AustriaHungary (London, 1972); F.R. Bridge, Great Britain and Austria-Hungary, 1906-1914: A Diplomatic History (London, 1972); G.P. Gooch, History of Modern Europe, 1878-1919 (London, 1924); G.P. Gooch, Before the War. Studies in Diplomacy: The Grouping of the Powers (London, 1937).

27. See Ünal, Ottoman Foreign Policy, op.cit., pp.78-81.

28. Vlakhov, op.cit., p.155.

29. For instance, on July 21, the Bulgarian agent at Monastir reported that the Young Turks had asked the Greeks to desist from attacking the Bulgarians, a policy that had been favoured and even perhaps fostered by the previous regime. See, for details, Vlakhov, op.cit., pp.143-5.

30. See note 22 .

31. Vlakhov, op.cit., pp.147-8.

32. Sir Charles Hardinge (Under-Secretary in the British Foreign Office) to Sir Francis Bertie (British Ambassador at Paris), 30.07.08, Pte. Bertie Papers (hereafter BP), (FO800/180).

33. P. Goranov, 'Tarnovskiyat Akt ot 5 oktomvri 1908g', in Todorova \& Statelova, op.cit., pp.119-21.

34. Goranov, op.cit., in Todorova and Statelova, op.cit., pp.122-3.

35. According to Lowther, the Bulgarian Agent was not invited because he was not a foreign representative but an Ottoman official. See, for instance, FO371/550,31758.

36. Paprikov told the Serbian Diplomatic Agent at Sofia, Svéta Simitch, that the Young Turks' nationalism was to blame for the incident. They wished to manifest the vassal status of Bulgaria. The Young Turks might have done it to simply turn the public attention from internal difficulties to something which, they thought, could enhance their chances before the upcoming elections. See Nintchitch, op.cit., p.263.

37. See, for details of the Incident, Crampton, op.cit., p.310; Bayur, op.cit., pp.259-61; E. Driault and M. l'Héritier, Histoire Diplomatique de la Grèce, de 1821 à nos jours (Paris, 1926), V., pp.12-13.

38. Bayur, op.cit., p.261, note 1 .

39. Bayur, op.cit., pp.260-261. Later, the Porte also tried to say in vain that, as the banquet was to take place at the Foreign Minister's own house, there was not enough room to invite Geshov because even other Ambassadors were invited on their own (Grand Vizierate to the Ottoman Commission in Sofia, undated, AMTZ, 170/77)

40. See, Die Grosse Politik der europäischen Kabinette 1871-1914 (hereafter, Die Grosse Politik), ed. by J. Lepsius, A. Mendelssohn-Bartholdy and F. Thimme (Berlin, 1922-27) 
26/1. nos: 8948-8949.

41. Nintchitch, op.cit., I., p.263. See, also, Geshov to Tevfik Pasha, Ottoman Minister for Foreign Affairs, 13 Sept. 08, AMTZ, 170/77. Although it has been assumed that the Porte responded to Geshov's departure with a tit for tat and recalled its representative in Sofia (Crampton, op.cit., pp.310-12), evidence in the Ottoman Archives suggests that the Ottoman Imperial Commissioner, Kâmil Bey, had in fact been summoned by the new regime before the Geshov Incident occurred possibly due to the part he had played in the Sultan's 'plot' at the outset of the Young Turk revolution to divert attention from the revolutionary movement. Kâmil Bey later in the Young Turk era was put on trial for embezzlement committed while in office in Sofia (Ottoman documents, AMTZ, 175/30; İrâde-i Hariciye, January 1911, No.2621). Ottoman documents do not indicate whether his trial had anything to do with this plot.

42. Crampton, op.cit., pp.310-12.

43. Refik Bey to Kâmil Pasha 15 Sept. 1908, AMTZ 170/77.

44. Crampton, op.cit., p.310.

45. See AMTZ documents dated between 15 and 22 September, 179/77. Pallavicini, the Doyen of the Diplomatic Corps, had at the time complained to the Porte at Geshov's inclusion with other foreign representatives on the occasion of the Sultan's proclamation of the Constitution on 24 July. Geshov had not been invited to the funeral of the British Ambassador who had died in Constantinople in March 1908. Lowther to Grey, 15 Sept. 1908, FO371/32154.

46. Ibid. He also said that he was doing all in his power to keep the press from going to extremes.

47. Refik Bey to Kâmil Pasa, 16 Sept. 1908, AMTZ, 170/77.

48. AMTZ, 170/17, 170/69, 170/70, 171/50.

49. AMTZ, 170/70; 171/17; Crampton, op.cit., p.311.

50. See, for instance, AMTZ, 170/69; 170/70; 170/77; Crampton, op.cit., p.311.

51. Mehmed Şükrü Bey to the General Staff (Umur-1 Erkân-1 Harbiye Dairesi), 22 Sept. 191908, AMTZ, 170/17.

52. The Ministry for Trade and Public Works to the Grand Vizierate, 22 Sept. 1908, AMTZ, 170/69; AMTZ, 170/77; AMTZ, 170/70; Ministry for Trade and Public Works to the Grand Vizierate, 25-26-27 Sept. 1908, AMTZ, 170/50.

53. 'The seizure by the Bulgarian railway administration of the use of the Oriental Railway Company has taken place as a result of a strike and an understanding with the representative of the railway company. Therefore, the restoration of this line to the said company is a question that will be resolved between the government of the Principality and the Oriental Railway Company.' For details of the history of the lines and so forth, see the lengthy note-verbale by the Bulgarian Foreign Office to the Powers and to the Ottoman Vice-Commissioner, Refik Bey, 24 Sept. 1908, AMTZ, 171/50.

54. Ibid.

55. Bayur, op.cit., pp.259-61.

56. Ibid., p.262.

57. Vlakhov, op.cit., pp.172-3.

58. B. Samardziev, 'Great Britain's Policy towards the Declaration of Bulgarian Independence, 1908-1909', Bulgarian Historical Review, Vol.4 (1987), pp.33-4.

59. Samardziev, op.cit., pp.33-4. Kalchov is supposed to have seen Lowther, who allegedly gave full backing to the plan agreed between the former on the one hand and the Young Turks and Kâmil Pasha on the other. However, this should be taken with a grain of salt not least because the whole mission is mentioned neither in British documents (FO371/550551; Lowther Papers, hereafter LP, FO800/193A-B), nor in the memoirs of Kâmil Pasha and Ahmed Riza. See, for instance, Bayur, op.cit.; Ahmed Rıza, Meclis-i Mebusan ve Ayan Reisi Ahmet Riza Bey'in Antlart (Istanbul, 1988).

60. Refik Bey to the Grand Vizierate, 22 Sept. 1908, AMTZ, 170/72.

61. AMTZ, 171/25.

62. Bertie to Grey, 3 Oct. 1908, FO371/550,32245,34247,34248; Lascelles to Grey, 04.10 .1908 , FO371/550,34261,34274. 
63. See, for all these details, Ünal, Ottoman Foreign Policy, pp.93-6.

64. The Bulgarian Foreign Minister had already admitted in his instructions to Shopov, who was negotiating with the members of the CUP following Geshov's recall by Bulgaria, that the Sofia government would use the Geshov Incident for a declaration of independence. See, for instance, Vlakhov, op.cit., pp.172-3; Crampton, op.cit., pp.311-12.

65. Crampton, op.cit., p.310.

66. The General Staff to the Grand Vizierate, 30 Sept. 1908 AMTZ,171/32.

67. The General Staff to the Ministry of War, 01.10.1908, AMTZ,171/29; Second Army Corps Deputy-Commander to the General Staff, and the War Ministry to the Grand Vizierate, 23 Sept. 1908, AMTZ, 171/77.

68. General Staff to the War Ministry 27 Sept. 1908; War Ministry to the Grand Vizierate, 5 Oct. 1908, AMTZ, 171/37.

69. General Staff to the Grand Vizierate, 04 Oct. 1908, 171/74; AMTZ, 171/76.

70. Buchanan to Grey, 18 Sept. 1908, FO371/551,32430. Paléologue, French Minister at Sofia, confirmed this information. See Paléologue to Pichon, 29 Sept. 1908, DDF 2ème Série, XI. No.471.

71. Mehmed Şükrü Bey to the General Staff and the General Staff to the Grand Vizierate, 14 Oct. 1908, AMTZ, 171/77.

72. See, for the French text and the Ottoman translation of the letter, Ottoman Foreign Ministry to the Grand Vizierate, 5 Oct. 1908, AMTZ, 171/36.

73. Mehmed Şükrü Bey to the General Staff and the General Staff to the Grand Vizierate 14 Oct. 1908, AMTZ, 171/77.

74. Ali Hilmi Bey, Second Secretary in the Ottoman Commission, to the General Staff, 10 Oct. 1908, AMTZ 171/77. See, also, Commander of the Second Army Corps to the General Staff, and the General Staff to the Grand Vizierate, 3 Oct. 1908, AMTZ, 171/77; Refik Bey to the Grand Vizierate, 3 Oct. 1908, AMTZ, 171/17; the General Staff to the Grand Vizierate 15 Oct. 1908, AMTZ, 171/17.

75. Ali Hilmi Bey, to the General Staff, 10 Oct. 1908, AMTZ 171/77; Commander of the Second Army Corps to the General Staff and the General Staff to the Grand Vizierate, 3 Oct. 1908, AMTZ, 171/77.

76. The British War Office assessments confirmed that the Bulgarian army was capable of striking a knock-out blow at the onset of the war (FO371/551,35118).

77. A.F. Türkgeldi, Görüp İşittiklerim (Ankara, 1951), p.12.

78. See, for details, Ünal, Ottoman Foreign Policy, pp.121-2.

79. AMTZ, 171/41.

80. Paléologue to Pichon, 7 Oct. 1908, DDF No.484.

81. Refik Bey to the Grand Vizierate 15 Oct. 1908, AMTZ, 172/18.

82. Refik Bey to the Grand Vizierate, 23 Oct. 1908, AMTZ, 171/85.

83. Todorova and Statelova, op.cit., no.60.

84. Ibid., No.61.

85. Refik Bey to the Grand Vizierate, 2 Oct. 1908, AMTZ, 172/8; Buchanan to Grey, 5 Oct. 1908, FO371/555,38553.

86. Todorova and Statelova, op.cit., p.129.

87. 'Discours de Faik Bey' in Refik Bey to the Grand Vizierate, 22 Oct. 1908, AMTZ, 171/5; $171 / 86$

88. 'Déclaration du Comité allié sur nos relations actuelles avec la Turquie', Ibid.

89. For French documents, see despatch from Salonique, 25 Oct. 1908, Nouvelle Série, Turquie, 192.

90. Lowther to Grey, 20 Oct. 1908 and 21 Oct. 1908, FO371/553,36535,36536.

91. See FO371/552,35743; FO371/553,36139,36184; FO371/554,37433.

92. Hardinge's minute on the Military Attaché's report in Hohler to Grey, 21 Oct. 1908, FO371/554,37120; Grey to Buchanan, 19 Oct. 1908, FO371/553,36528; cf. Rifat Pasha to the Foreign Ministry, and the Foreign Ministry to the Grand Vizierate, 29 Oct. 1908, AMTZ, 171/77.

93. See minute by Hardinge on Lowther to Grey, 30 Oct. 1908, FO371/554,37763. See also minutes by Hardinge on a similar despatch from the Military Attaché in Constantinople in 
Hohler to Grey, 20 Oct. 1908, FO371/553,36522.

94. Grey to Lowther, 30 Oct. 1908, and Lowther to Grey, 1 Nov.1908, FO371/554,34877.

95. Grey to Lowther, 3 Nov. 1908, FO371/555,38214. See, also, Hardinge to Lowther, 3 Oct. 1908, Pte. Hardinge Papers (hereafter HP.); LP (FO800/193A).

96. Türkgeldi, op.cit., pp.11-12. Romania immediately consulted Austria-Hungary and subsequently declined to consider the Ottoman proposal. For details, see Szápáry to Aehrenthal, 2 Jan. 1908, Österreich-Ungarns Aussenpolitik von der bosnischen Krise 1908 bis zum Kriegsausbruch, ed. by L. Bittner and Uebersberger (Vienna, 1930) (hereafter $O U A$ ), I., nos: 108-9.

97. See Y. Kamil Paşa., 86/33,3242.

98. Lowther to Grey, 12 Oct. 1908, 13 Oct. 1908, 14 Oct. 1908 and 15 Oct. 1908, FO371/552,35514,35537,35667.

99. Y. Kamil Paşa, $86 / 33,3242$.

100. Copy of the Draft Treaty, 10 Oct. 1908, Y. Kamil Paşa, 86/33,3242.

101. D. Dakin, The Unification of Greece, 1770-1923 (London, 1972), pp.149-58, 170-3, 178-9.

102. Driault and 1'Héritier, op.cit., pp.13-14. For details of Greek public opinion in the immediate aftermath the Young Turk revolution, see S. Papadopoulos, 'La Révolution des 'Jeunes-Turcs' et l'Opinion Publique en Grèce', Balkan Studies, Vol.27 (1986), pp.129-37.

103. Elliot to Grey, 11 Nov. 1908, FO371/551,35193; Potalis to Pichon, 11 Oct. 1908, Nouvelle Série, Turquie, 190.

104. See Elliot to Grey, 11 Nov. 1908, FO371/552, 35235. French documents confirm all this. See, Potalis to Pichon, 11 Oct. 1908, Nouvelle Série, Turquie, 190.

105. 'Not only desirous of establishing best friendly relations with the neighbouring Empire, but also desirous of seeing the closest rapprochement between the two countries established'. Elliot to Grey, 14 Nov. 1908, FO371/552,35599.

106. Elliot to Grey, 12 Nov. 1908 , FO371/556,40378.

107. Ibid., minute.

108. See H. Noradonghian, Vers la Guerre balkanique et la Première Guerre Mondiale (Istanbul, 1950), pp.9-13.

109. Bridge, From Sadowa to Sarajevo, pp.277-80.

110. For details of the Serbo-Montenegrin military convention, see J.D. Treadway, The Falcon and the Eagle, Montenegro and Austria-Hungary, 1908-1914 (West Lafayette, Indiana: Purdue University Press, 1983), pp.30-1; Nintchitch, op.cit., II., pp.83-4.

111. Whitehead to Grey, 27 Oct. 1908, FO371/554,37895. Although the Serbs and the Montenegrins made every effort to assure the Ottoman representative at Belgrade that their convention was not aimed at further spoliation of the Ottoman Empire, it appears that they had every intention to satisfy their ambitions by linking the two countries through the Ottoman province of Sanjak of Novi Bazar. See, for the text of the convention, Nintchitch, op.cit., II., pp.83-4; Treadway, op.cit., p.31.

112. Before his departure for Constantinople, Novaković said that his intention was to conclude an entente with the Porte with a view to putting the question of the annexation on the conference programme and demanding autonomy under the suzerainty of the Sultan and the appointment of a prince nominated by the Powers. See, the despatch from Belgrade in Nouvelle Série, Turquie, 27 Oct. 1908, 192.

113. Lowther to Grey, 16 Nov. 1908 , FO371/556,40059.

114. See, the copy of the draft alliance dated 5 Nov. 1908, Y. Kamil Paşa, 86/33,3242.

115. Article 1 of the Draft Convention, Ibid.

116. Second Clause of the Draft Convention, Ibid.

117. Third Article of the Draft Convention, Ibid.

118. Fourth Clause of the Convention, Ibid.

119. Articles Five, Six and Seven, Ibid.

120. Ibid. cf. Whitehead to Grey, 10 Nov. 1908, FO371/555, 39248 and Whitehead to Grey, 10 Nov. 1908, FO371/555,39856.

121. Whitehead to Grey, 10 Nov. 1908, FO371/555,39856.

122. Whitehead to Grey, 13 Nov. 1908, FO371/555,39596. 
123. They asked Britain that until 'the proper moment had arrived' Lowther should refrain from referring to the negotiations in any manner or form (Whitehead to Grey, 25 Nov. 1908, FO371/557,41711).

124. These fears were expressed by the Serbian Military Attaché in Bulgaria to Mehmed Şükrü Bey at the end of November. See Mehmed Şükrü Bey to the General Staff and the Grand Vizierate, 23 Nov. 1908, AMTZ, 173/22.

125. Whitehead to Grey, 2 Dec. 1908, FO371/557,42134.

126. Kâmil Pasha had already told Novaković that the idea of a military alliance had collapsed. Constans to Pichon, 17 Nov. 1908, Nouvelle Série, Turquie, 192.

127. Lowther to Grey, 12 Nov. 1908 , FO371/555,39497.

128. Lowther to Grey, 14 Dec. 1908 , FO371/558,43731.

129. Lowther to Grey, 26 Oct. 1908, and Grey to Lowther, 28 Oct. 1908, FO371/554,37298, and minutes. On the Porte's approach to Greece, Grey had instructed Elliot to inform the Greeks of the Foreign Office's view that in the event of Bulgaria attacking Turkey, the latter should be given moral support' (Elliot to Grey and Grey to Elliot, 28 Oct. 1908, FO371,554,37298, and minutes). In a similar fashion, Whitehead was furnished with instructions to discourage the idea of a defensive and offensive alliance, which might be directed against Bulgaria and even Austria-Hungary, on the grounds that such an OttomanSerbian combination would ultimately push Sofia into the arms of the Dual Monarchy. See, Whitehead to Grey, 13 Nov. 1908, and Grey to Whitehead, 14 Nov. 1908, FO371/556, 41617, and minutes; Whitehead to Grey, 10-13 Nov. 1908, FO371/555, 39596,39856. In the same manner, the British endeavoured to dissuade the Montenegrins from seeking an alliance with the Ottoman Empire. See, Lowther to Grey, 16 Nov. 1908, FO371/556,40059; Grey to O'Reilly, 17 Nov. 1908, FO371/556,40059.

130. Ibid. For further information, see, Whitehead to Grey, 25 Nov. 1908, FO371/557,41711; Greene to Grey, 1909 Dec. 1908, FO371/558,43535. For Whitehead's attempts to discourage the Serbs from forming such an alliance, see, Whitehead to Grey, 02 Dec. 1908, FO371/557,42134;FO371/558,43516; Grey to Lowther, 10 Nov. 1908, FO371/555,38062.

131. See Hardinge to Lowther, 1 Dec. 1908, Pte., HP. 11; LP (FO800/193/A). See also M.B., Cooper, 'British Policy in the Balkans, 1908-1909', The Historical Journal, Vol.7, No.2 (1964), pp.275-7.

132. See, 'Jeunes Turcs à Paris', 14 Nov. 1908, Nouvelle Série, Turquie, 193-194.

133. Grey and Hardinge also advised the same delegation to conclude an alliance with the Balkan states, including Bulgaria. See, Grey to Lowther, 14 Nov. 1908, Pte.. GP. (FO800/79); LP (FO800/193A).

134. Hardinge's minute on Greene to Grey, 23 Dec. 1908, FO371/558, 45119.

135. See, for details, Thaden, op.cit., pp.17-21.

136. E.C. Helmreich, The Diplomacy of the Balkan Wars, 1912-1913 (Harvard University Press, 1938), p.20.

137. See, for instance, 'Note des türkischen Botschaftsrates Reschad Hikmet', 7 Oct. 1908, OUA, I., No.173; 'Vom türkischen Botschafter in Berlin Tewfik Pascha am 7 Oktober 1908 dem Stellvertretenden Staatssekretär Stemrich überreicht', 7 Oct. 1908, Grosse Politik., Vol.26/1, No.8973.

138. AMTZ, 172/14.

139. See the memorandum by von Griesinger, 6 Oct. 1908, Grosse Politik., Vol.26/2, No.9289.

140. Grey to Lowther, 26 Oct. 1908, FO371/554,37601.

141. Refik Bey to the Grand Vizierate, 23 Oct. 1908, AMTZ, 171/85.

142. Lowther to Grey, 30 Nov. 1908, FO371/557,41878; Marschall to the German Foreign Office, 26 Oct. 1908 and 30 Oct. 1908, Grosse Politik., Vol.26/2, nos.9290, 9291.

143. Marschall to the German Foreign Office, 4 Nov. 1908, Grosse Politik., Vol.26/2, No.9287.

144. Refik Bey to the Grand Vizierate, 2 Nov. 1908, AMTZ and 5 Nov. 1908, AMTZ, 172/22.

145. See, Todorova and Statelova, op.cit., No.73; Y. Kâmil Paşa., 30 Oct. 1908, 86/33,3268.

146. See, for instance, Refik Bey to the Grand Vizierate, 11 Nov. 1908, AMTZ, 172/34.

147. Minutes on Lowther to Grey, 30 Nov. 1908, FO371/557,41878.

148. Lowther to Grey, 30 Nov. 1908, FO371/557,41878; Marschall to the German Foreign Office, 26 Oct. 08 and 30 Oct. 1908, Grosse Politik., Vol.26/2, nos: 9290, 9291; Constans 
to Pichon, 12 Nov. 1908, Nouvelle Série, Turquie, 193-4.

149. Kâmil Pasha to Prince Ferdinand, 30 Nov. 1908, Y. Kamil Paşa., 86/33,3268. For the French text, see, Todorova and Statelova, op.cit., No.73.

150. Grey to Nicolson, 13 Nov. 1908, FO371/555,39495.

151. French estimates fixed the sum at $\mathrm{T} £ 5,680,000$ (Bertie to Grey, 17 Jan 1909, FO371/747,2145, and the minutes).

152. See, Refik Bey to the Grand Vizierate, 11 Nov. 1908, AMTZ, 173/34; Refik Bey to the Grand Vizierate, 12 Nov. 1908, AMTZ, 172/53; Refik Bey to the Grand Vizierate, 17 Nov. 1908, AMTZ, 172/55.

153. AMTZ, 172/45; AMTZ, 171/35, 171/46.

154. In this speech allusion had been made to Ferdinand as the Prince of Bulgaria and Governor of Eastern Rumelia, who, having broken his oath allegiance to the Sultan, had, for some reason, declared independence (Lowther to Grey, 17 Dec. 1908, FO371/558,44097).

155. See, for the text of the note, Refik Bey to the Grand Vizierate, 24 Dec. 1908, AMTZ, $173 / 47$.

156. Ibid. See also Refik Bey's comments in his covering letter in the same file, AMTZ, 173/47.

157. See, Refik Bey to the Grand Vizierate, 2 Jan. 1909, AMTZ, 173/60.

158. See, Ünal, Ottoman Foreign Policy, op.cit., pp.223-227.

159. Refik Bey to the Grand Vizierate 12 Jan. 1909, AMTZ, 173/67.

160. Grey to Buchanan, 16 Jan. 1909, FO371/748,2051.

161. Grey to Lowther, 19 Jan. 1909, FO371/748,3427.

162. Grey to Buchanan, 16 Jan. 1909, FO371/748,2051.

163. Grey to Nicolson, 11 Jan. 1909, FO371/747,1003.

164. See, all the reports from Nicolson to Grey, 23-24 Jan. 1909, FO371/748,3070,3072,3073. The British Foreign Office thought that it could neither accept nor recommend Izvolsky's proposal to the Porte (Ibid., minutes).

165. Pallavicini to Aehrenthal, 12 Jan. 1909, OUA, I., No.880.

166. In a memorandum communicated to Benckendorff, Grey did not seem unfavourable to the Grand Vizier's scheme (Memorandum communicated to Benckendorff, 28 Jan. 1909, FO371/749,3838,3844). Izvolsky equally expressed himself favourable to some very slight frontier rectifications (Nicolson to Grey, 20 Jan. 1909, FO371/748,3148).

167. There is no copy of the Kâmil's letter to Sofia in the Ottoman archives. But his letter is largely summarised in the Bulgarian note to the Powers. See, AMTZ, 174/9.

168. See, reports from the province of Adrianople and the Interior Ministry about these preparations, Interior Ministry to the Grand Vizierate, 4 Jan. 1909, AMTZ 173/73. There is another report from the War Ministry on rumours circulated among the Bulgarian population in Macedonia that Bulgaria was about to move against the Empire. See, War Ministry to the Grand Vizierate, 16 Jan. 1909, AMTZ, 173/88.

169. The Chief of Staff to Kamil Pasha, 25 Jan. 1909, Y. Kamil Paşa., 86/32,3135.

170. The Chief of Staff to the Grand Vizier, 25 Jan. 1909, Y. Kamil Pasa., 86/32,3135.

171. Ibid.

172. Y. Kamil Paşa., 86/34,3351.

173. Ottoman military preparations were of a 'negligible' nature. Although they were made to guard against a possible sudden Bulgarian attack, it seems that even such a small objective might have proved difficult for the Empire to achieve. See Y. Kamil Paşa., 86/32,3135. Neither Lowther nor the British Military Attaché, Colonel Surtees, believed that the Empire's military measures were intended for offensive purposes, nor that the Porte entertained any idea of seizing Bulgarian territory by force. See, Lowther to Grey, 26 Jan. 1909, FO371/748,3466; Lowther to Grey, 27-28 Jan. 1909, FO371/749,3688, 3689; Lowther to Grey together with the British Military Attache's report dated 19th January, 20 Jan. 1909, FO371/748,3498.

174. See AMTZ, 173/73; 173/77; 173/81; 173/88; 174/1; 174/3; 174/4; 174/5; 174/13; 174/19; 174/55. Kamil Pasha also feared that war with Bulgaria would hold back the Empire's economic development (Y. Kamil Paşa., 86/32,3137).

175. Lowther to Grey, 26 Jan. 1909, FO371/748,3491.

176. Lowther to Grey, 27 Jan. 1909, FO371/749,3688. 
177. Ibid.

178. Grey to Lowther, 27 Jan. 1909, FO371/749,3904.

179. Nicolson to Grey, 29 Jan. 1909, FO371/749,3947.

180. For details of the war indemnity, see M.R. Milgrim, 'An Overlooked Problem in TurkishRussian Relations: The 1878 War Indemnity', International Journal of Middle Eastern Studies, Vol.9 (1978), pp.519-37.

181. Grey to Nicolson, 30 Jan. 1909, FO371/749,3947.

182. Buchanan to Grey, 1 Feb. 1909, FO371/749,4340,4341; Buchanan to Grey, 30 Jan. 1909, FO371/749,3953.

183. Lowther to Grey, 1 Feb. 1909, 2 Feb. 1909 and 3 Feb. 1909, FO371/749, 4342,4487, 4587.

184. Lowther to Grey, 30 Jan. 1909, FO371/750,5066; Lowther to Grey, 4 Feb. 1909, FO371/749,4618; Nicolson to Grey, 3-4 Feb. 1909, FO371/749,4584,4762,4770.

185. See, for Kamil Pasha's reservations about the Russian proposal, Lowther to Grey, 1 Feb. 1909, 2 Feb. 1909, 3 Feb. 1909 and 4 Feb. 1909, FO371/749,4342,4618,5066; Lowther to Grey, 5 Feb. 1909, FO371/749,750,4861.

186. Grey to Lowther, 2 Feb. 1909, 3 Feb. 1909, 4 Feb. 1909 and 5 Feb. 1909, FO371/749, $4342,4587,4588,4618$.

187. Hardinge to Lowther, 6 Feb. 1909 , Pte. $L P($ FO800/193A).

188. 'Reply of the Turkish Government to the Russian Proposal respecting Turkish Claims against Bulgaria' in Lowther to Grey, 6 Feb. 1909, FO371/750,5741.

189. Grey to Nicolson, 12 Feb. 1909, FO371/750,5893; FO371/750,5741; Nicolson to Grey, 15 Feb. 1909, FO371/750,5977, and minutes; Grey to Nicolson, 15 Feb. 1909, FO371/750,6460; Grey to Nicolson, 12 Feb. 1909, FO371/750,5893; Grey to Nicolson, 02 Feb. 1909, Pte. GP.(FO800/73); Grey to Poklewski, 12 Feb. 1909, Pte. GP.(FO800/73).

190. Nicolson to Grey, 04 March 1909, 07 March 1909, FO371/752,8578,8857.

191. But Izvolsky insisted that Rifat's promise be put in writing. Rifat Pasha objected that he could not do so without consulting his cabinet colleagues. Nicolson to Grey, 4 March 1909 and 5 March 1909, FO371/752,8578,8693; Nicolson to Grey, 8 March 1909, FO371/753,9768.

192. Nicolson to Grey, 7 March 1909, FO371/752,8857; Nicolson to Grey, 15 March 1909, FO371/753,100008; Nicolson to Grey, 8 March 1909, FO371/753,9768.

193. For the text of the protocol, see 'Rifat Pasha to Haridjie'' in Lowther to Grey, 18 March 1909, FO371/754,10803.

194. For the text of this alleged treaty, see Lowther to Grey, 18 March 1909 , FO371/754,10392.

195. AMTZ, 174/41.

196. Refik Bey to the Grand Vizierate, 21 March 1909, and Hüseyin Hilmi Pasha to Refik Bey, 23 March 1909, AMTZ, 174/41.

197. Türkgeldi, Görüp İşittiklerim, pp.13-14.

198. For information about growing domestic tension, see Akşin, 31 Mart Olayı (Istanbul, 1972).

199. See, for the detailed correspondence between Refik Bey and the Porte regarding Bulgaria's efforts for early recognition, AMTZ, 174/67.

200. He had, in fact, been in favour of early recognition. See AMTZ, 174/67.

201. Nicolson to Grey, 15 April 1909, FO371/757,14199; Buchanan to Grey, 13 April 1909, FO371/757,13945, and minutes.

202. Ibid., Mallet's minute; FO371/757,14324.

203. Grey to Nicolson, 16 April 1909, FO371/757,14199.

204. Lowther to Grey, 14 April 1909, 15 April 1909, 17 April 1909, and 18 April 1909, FO371/757,14034,14122,14176,14188,14192,14199,14414,14490.

205. For Mahmud Şevket Pasha and the 'Army of Operations', see G.W. Swanson, Mahmud Sevket Paşa and the Defense of the Ottoman Empire: A Study in War and Revolution During the Young Turk Period (Unpublished Ph.D. thesis, Indiana University, Department of History, 1970), pp.51-73.

206. Lamb to Lowther, 24 April 1909, FO195/2330.

207. See, for the text of the Protocol, K. Strupp, Ausgewählte diplomatische Aktenstücke zur orientalischen Frage, X. (Gotha, 1916) pp.245-6. 
208. Grey to Buchanan, 21 April 1909, FO371/757,15142; Grey to Nicolson, 4 May 1909, FO371/757,16472; Bertie to Grey, 4 May 1909 and 5 May 1909, FO371/758,16950,17123.

209. Y.H. Bayur, Türk İnklabt Tarihi (Ankara, 1983), I/2, pp.172-3; FO371/758,18450.

210. See, for the CUP's inconsistent and contradictory efforts of diplomacy during the Bosnian annexation crisis, H. Ünal, 'Young Turk Assessments', op.cit. 